\title{
Smisao univerziteta: Heideggerov ambivalentni odnos prema univerzitetu
}

\author{
DUNJA MELČIĆ
}

\begin{abstract}
Sažetak
Može se reći da je ideja univerziteta bila Heideggerova životna opsesija. Moć obrazovanja, u koju je vjerovao već u mladosti, bila je za njega moć za mijenjanje. U početku ju je smještao u okvire kršćanstva i njegova naslijeđa. Modernističko znanstveno propitivanje vidio je kao potragu za istinom, koja je trebala biti kršćanska istina. Najmodernija metoda filozofije bila je tada Husserlova fenomenologija, koju je Heidegger koristio za kritičko ispitivanje tradicije u europskom filozofskom, metafizičkom mišljenju. No nakon katastrofe koju je sobom donio Veliki (Prvi svjetski) rat, Heidegger, koji već tada predaje, uviđa nužnost za radikalnim preokretom u odnosu na tradicionalni univerzitet prema potpuno novom početku. On se okreće ka prvom buđenju pitanja o bitku kao takvom - u antičkoj Grčkoj. Svojim fantastičnim predavanjima, svojim dubokim a ipak prema stvarnosti okrenutim mišljenjem, modernim pristupima i prema svemu otvorenim metodama pokušao je na univerzitetu učiniti istinsku promjenu i potencijalno novi početak. Pritom je međutim bio nekritičan prema svom činjenju. Nije ga kritički razmatrao, nego je počeo vjerovati da je uništavanje "starog svjetskog poretka" i "fosiliziranih" institucija opravdano jer je došlo vrijeme za revolucioniranje univerziteta i akademskog obrazovanja. Sve dok nije postao rektor Univerziteta u Freiburgu (1933) gotovo nitko nije znao za njegov pojam "potpuno novog univerziteta". On je međutim smatrao da se ta ideja uklapa u koncept "nacionalsocijalističkog univerziteta". Središnja ideja tog koncepta je ideja volje (der Wille), iako tek pretpostavljene volje. Čak je i nakon debakla te svoje sramotne epizode Heidegger nastavio fantazirati o nekom drukčijem univerzitetu, ali je odustao od ideje volje. No čak ni u tim kasnijim spisima ne možemo pronaći neku iskrenu analizu vlastitih postupaka. Umjesto toga on sažalijeva svoju sudbinu, tvrdeći da njegove ideje nisu bile pogrešne, nego samo da nije bilo vrijeme za njih. To što je bio dio kriminalnog ubilačkog režima nikad nije tretirao kao problem. U tome je i glavni razlog njegove notorne šutnje o vlastitoj krivici ili odgovornosti tijekom nacionalsocijalističkog poretka. Paradoks je u tome što usporedna analiza njegovog javnog govora i predavanja i onoga što je pisao privatno otkriva Heideggerovu dvojnu prirodu. Nakon što mu je oduzeto pravo predavanja na univerzitetu, on doživljava stvarnu traumu jer mu ne nedostaje neki
\end{abstract}


zamišljeni "drukčiji univerzitet”, nego onaj stvarni. S jedne strane kritizira liberalni duh univerziteta, a s druge je upravo on profitirao zbog liberalnog duha univerziteta kao moderne institucije koja omogućuje slobodno mišljenje, pozivajući se na duh slobode utemeljen još kod grčkih klasika.

Ključne riječi: Heidegger, univerzitet, “nov početak”, nacizam, volja

U spomen na velikoga Slavka Goldsteina

\section{Uvod: ekspozicija tematike}

Predmet ovog članka je kontroverzni Heideggerov odnos prema instituciji i problemu univerziteta u svjetlu novijih publikacija. ${ }^{1}$ Pitanje univerziteta, filozofije na univerzitetu, učenja, preciznije: prijenosa znanja, mišljenja, mogućnosti komunikacije i egzistencijalnog preobrata putem znanja je Heideggerova konstantna preokupacija, pri čemu njegova kritička promatranja kompletno dovode u pitanje smisao modernog (novovjekovnog) univerziteta. Cijeli taj spektar izlazi izrazitije na vidjelo nakon objavljivanja niza prepiski s kolegama i suvremenicima te privatnih, za života neobjavljenih zapisa, naročito u zadnja dva desetljeća do 2017. Pitanje univerziteta bi se moglo slobodno nazvati Heideggerovom životnom opsesijom. U njemu gori želja za preoblikovanjem 'realno egzistirajućeg' univerziteta i sistema obrazovanja. Zapravo jedan poriv koji bi mogao biti povezan s tim stremljenjem za totalnom promjenom i obnovom univerziteta nazire se već u najranijim objavljenim radovima - prvim člancima i recenzijama (1912-1916) te dizertaciji (Die Lehre vom Urteil im Psychologismus, 1913) i habilitacijskom radu (Die Kategorien- und Bedeutungslehre des Duns Scotus, 1915): to je naime kritičko propitivanje naslijeđenog, dovođenje u pitanje tradicionalnog mišljenja, učenja, dogmi u potrazi za izvornijim oblicima duhovne artikulacije, a u zadatim okvirima katoličkog svjetonazora, koji je u

${ }^{1}$ Iako je od Heideggerovog ogromnog opusa najveći dio već objavljen u ediciji "Sveukupna djela" (Gesamtausgabe = GA, tu kraticu koristim u daljnjem tekstu), ona predviđaju još nekoliko tomova; "Sveukupna djela" izlaze kod nakladnika Klostermann u Frankfurtu. Tekstovi koji su objavljeni zadnjih godina su njegova predavanja te razne bilješke, dnevnički zapisi, osim toga važne prepiske: Martin Heidegger/Elisabeth Blochmann, Briefwechsel 1918-1969, prir. Joachim W. Storck, Deutsche Schillergesellschaft, Marbach 1989; Hannah Arendt/Martin Heidegger, Briefe 1925 bis 1975 und andere Zeugnisse, prir. Ursula Ludz, Frankfurt 1998; "Mein liebes Seelchen!" Briefe Martin Heideggers an seine Frau Elfride, 1915-1970, prir. Gertrud Heidegger, DVA, München 2005; R. Bultmann/M. Heidegger, Briefwechsel: 1925 - 1975, prir. Andreas Großmann \& Christof Landmesser, Siebeck/Klostermann, Frankfurt 2009; MH/Karl Löwith, Briefwechsel 1919-1973, prir. Alfred Denker, V. Karl Alber, Freiburg/München 2017. Pregled i aktualnosti na: https://de.wikipedia.org/wiki/Martin_Heidegger. 
mladosti još snažan, recimo u govoru 1910. g. povodom otkrivanja spomenika katoličkom propovjedniku, augustincu, Abrahamu a Sancta Clara u blizini njegovog rodnog Meßkircha, u kojem mladi Heidegger zacrtava potrebu "liječenja narodne duše" povratkom starim kršćanskim vrlinama po uzoru na svog zemljaka iz 17. stoljeća. ${ }^{3}$

Kao student Heidegger je posvećen interpretaciji srednjovjekovnog mišljenja i tomističke tradicije te "želi svoj životni rad usmjeriti na omogućavanje protočnosti (Flüssigmachung) misaone zaostavštine nataložene u skolastici u budućoj duhovnoj borbi za kršćansko-katolički životni ideal". ${ }^{4}$ To se odražava i u njegovim prvim člancima, recenzijama, u vidu skeptičkog odmaka od moderne i habitualnog konzervativizma. Ali istovremeno on prevodi taj katoličko-konzervativni diskurs iz skolastičkog naslijeđa u moderni način razmišljanja i nastoji ga obnoviti putem suvremenih filozofskih metoda. Tu se već da uočiti određena dvostrukost, dvije težnje koje se teško mogu pomiriti. Pogled unazad na Heideggerov misaoni i životni put omogućava zaključak da je ta dvostrukost njegov stalni moment. On sâm to ne tematizira direktno, ali - ne ulazeći u spekulativna psihologiziranja - može se ustanoviti da su dvostrukost i dvosmislenost česta tema njegove filozofske refleksije, naročito u predavanjima o bitnoj dvoznačnosti filozofije iz vremena Bitka $i$ vremena $(1929 / 1930){ }^{5}$

Mladi Heidegger je entuzijastički prihvatio novu Husserlovu fenomenološku metodu i u njezinoj je primjeni na temeljne, a tradicionalno zanemarene filozofske probleme dosegnuo vrhunce filozofskog propitivanja i deskripcije bitnih fenomena i sklopova uopće. Njegova habilitacija iz 1915. je prvi pokušaj sistematske primjene fenomenološke metode na sadržaje iz filozofske prošlosti, tj. skolastičke psihologije. U uvodu - pod znakovitim, upravo programatskim naslovom: "Nužnost problemsko-povijesnog razmatranja skolastike" - Heidegger "fenomenološkom razradom... štiva srednjevjekovne skolastike" želi doći do "temeljnog karaktera skolastičke psihologije" kako bi pokazao da je on potpuno različit od "moderne prirodnoznanstvene psihologije". ${ }^{6}$

Tu se nazire taj poriv za modernim, metodski osiguranim pronicanjem temelja bitnih filozofskih, metafizičkih problema s obzirom na njihov povijesni razvoj i otklanjanje korupcije bîti a da bi se došlo do izvornih značenja i time uspostavio jedan suštinski, životno relevantni sklop nasuprot postojećim modernim (percipira-

2 GA 13, “'Abraham a Sankta Clara' Zur Enthüllung seines Denkmals”, Aus der Erfahrung des Denkens 1910-1976, prir. Hermann Heidegger, Frankfurt 1983, str. 152.

${ }^{3}$ Vidi detaljnije: https://de.wikipedia.org/wiki/Abraham_a_Sancta_Clara.

${ }^{4}$ Iz obrazloženja molbe za stipendiju, citirano prema: Rüdiger Safranski, Ein Meister aus Deutschland. Heidegger und seine Zeit, München 1994, str. 65-66; dalje kao: Safranski.

${ }^{5}$ GA 29/30, Die Grundbegriffe der Metaphysik. Welt - Endlichkeit - Einsamkeit, Frankfurt 19832, str. 18-19.

${ }^{6}$ GA 1, Frühe Schriften, str. 205. 
no: površnim, odnosno iskrivljenim) tumačenjima i važenjima. Dakle opet podvojenost: metodsko moderniziranje filozofije, ali ne s težnjom za nečim novim, nego za vraćanjem starom, točnije - samom početku.

Izbijanjem Velikog (Prvog svjetskog) rata sve se mijenja i ništa ne ostaje neuvučeno u njegov totalitet. Strahote rata i sveopćeg uništenja stoje u pozadini sveprisutnog stremljenja za radikalnim promjenama na svim razinama života koje dolazi do izražaja u revolucijama i radikalnim političkim pokretima; uz to dolazi do ogromnih promjena načina razmišljanja, doživljaja svijeta i vremena. Mladi Heidegger za razliku od većine svojih vršnjaka zbog srčane disfunkcije nije početkom rata bio mobiliziran, te je mogao dovršavati svoj rad na skolastičkoj filozofiji, ali rat je bio sveprisutan i u njemu je raslo uvjerenje da ništa više ne može, odnosno ne smije ostati isto nakon što se moglo desiti takvo što strašno kao što je svjetski rat. Već tada to za njega znači da stari univerzitet ne smije više ostati isti, daleko od života i bez traga nekog upliva strašnih doživljaja rata koji je pogodio toliko mnogo mladih, a među njima je naravno bilo i puno studenata i akademskog podmlatka uopće.

Potreban je "novi početak": kad god Heidegger pomisli na univerzitet, tu je i misao o nužnom novom početku, cijeli sustav treba postaviti na nove temelje i sve mora biti drugačije. ${ }^{7}$

Taj radikalan stav kulminira u njegovom iznenadnom okretanju praktičnoj politici i preuzimanju dužnosti rektora Univerziteta u Freiburgu 1933. godine. Ali i nakon tog poraznog i sudbonosnog pokušaja realizacije dugo gajenih stremljenja Heidegger se uvijek ponovno vraća pitanju univerziteta. Poraz koji je doživio ga grize, ali i dalje se drži svoje ideje o njegovoj nužnoj preobrazbi - samo sad: jednom u budućnosti. Nebrojene primjedbe, komentari i kritičke osude stanja na instituciji univerziteta u Heideggerovom djelu i ostavštini svjedoče o tomu da se ipak radilo o njegovom usamljenom nastojanju, o kojem je tu i tamo korespondirao (u prepisci s Blochmannom, Bultmannom i naročito Jaspersom); očito je da on nije s nekim zajedno radio na projektu reforme univerziteta, s nekim timom razrađivao planove ili se pripremao na preuzimanje dužnosti rektora. Javno je svoju viziju budućeg sasvim drugačijeg univerziteta Heidegger formulirao tek nakon što je postao rektor freiburškog univerziteta. ${ }^{8} \mathrm{U}$ dokumentiranim službenim materijalima i prigodnim političkim govorima ogleda se pak kako bi egzistencijalno-ontološke ideje trebale

7 GA 56/57, Zur Bestimmung der Philosophie mit: Nachschrift der Vorlesung "Über das Wesen der Universität und des akademischen Studiums" (tzv. Kriegsnotsemester 1919), prir. Bernd Heimbüchel, Frankfurt 1999², str. 16, usp. "Obnova univerziteta znači preporod istinske znanstvene svijesti i životnog sklopa", str. 5.

${ }^{8}$ GA 16, Reden und andere Zeugnisse eines Lebensweges (1910-1976), prir. Hermann Heidegger, Frankfurt 2000, usp. naročito: "Die deutsche Universität" (Ausländerkurse, Aug. 1934), str. 285-307. 
postati temelj obrazovanja i univerziteta. Ali između toga i nekog razrađenog projekta sveobuhvatne reforme univerziteta zjapi velika praznina. ${ }^{9}$

Međutim pored tih razgranatih refleksija postoji i nešto drugo: Heidegger kao filozof i pedagog koji živi i radi na konkretno postojećem univerzitetu, predaje s velikim uspjehom, uči svoje studente filozofirati, obrazuje metodski njihov način mišljenja, shvaćanja fenomena i propitivanja problema. Taj drugi odnos prema univerzitetu bi se mogao nazvati pravim, živim, djelatnim i pitanje je gdje to što on kao konkretni filozof i pedagog jeste nestaje pod velebnom vizijom korjenitog preokreta njemačkog visokog školstva. U svojoj nastavničkoj djelatnosti on se osjeća "kao kod kuće". Taj zaključak se nameće kod pažljivog čitanja Heideggerovih izlaganja koja nisu bez razloga bila tako obljubljena među studentima i razvikana među njemačkom akademskom publikom. Te svoje bliske i najbliže egzistencijalne okolnosti on nije tematizirao. ${ }^{10}$

To zanemareno također je jedan faktor u načinu kako Heidegger misli univerzitet $u$ rascjepu između filozofije i univerziteta. ${ }^{11}$

Tu problematiku ću pobliže obraditi kroz osam manjih cjelina koje nisu oštro odijeljene jedna od druge jer se pojedini aspekti isprepliću pa se ne mogu odvojiti kao u geometriji uglati od okruglih oblika.

\section{Rektorat: čin i nadanja}

Što je za Heideggera bilo u fokusu kad se odlučio na svoj politički angažman: promjena univerziteta ili društvenog poretka? Što se može doznati o Heideggerovom odnosu prema univerzitetu u naznačenoj dilemi iz samog rektorskog govora, a što iz osvrta na rektorat iz 1945. - "nakon sloma"?

9 Zapisi pod naslovom "Razmišljanja" iz doba oko rektorata (1931-1938) sadrže opetovane refleksije vezane uz univerzitet i rektorat, konkretne događaje, ali i vrlo slobodna fantaziranja o univerzitetu odnosno njegovom kraju, čak "uništenju" te nekom sasvim drugačijem "znanju" i znanstvenom obrazovanju, GA 94, Überlegungen II-IV (Schwarze Hefte 1931-1938), prir. Peter Travny, Frankfurt 2014, str. 115.

${ }^{10}$ Ali barem kad ga sjećanja vraćaju vremenu u Marburgu - npr. u pismima Bultmannu - on postaje svjestan izuzetnosti marburškog vremena u svom životu, usp. pismo od 22. decembra 1948, str. 205; također u nekoliko kraćih pisama pred kraj života obojice prijatelja; jedno od 17. augusta 1974. je pravi mali hommage marburškom vremenu i dragocjenom prijateljstvu, R. Bultmann/M. Heidegger, Briefwechsel: 1925 - 1975, str. 252. Na mnogim mjestima u privatnim zapisima (GA 94 i 97) jasno se pokazuje da ga udaljenost od nastavne djelatnosti teško tišti - a tu se radilo naravno o konkretnom djelovanju unutar realno egzistirajućeg univerziteta.

${ }^{11}$ GA 94.

12 Martin Heidegger, Rektorski govor (RG), "Rektorat 1933./34. Činjenice i misli”, Zagreb 1999; priređivač prvog izdanja iz 1983, Heideggerov sin Hermann, piše u predgovoru da mu je otac dao rukopis osvrta uz uputu da ga objavi kad se za to ukaže vrijeme, što je on učinio zajedno s novim izdanjem rektorskog govora. 
Heideggerov rektorski govor je izlaganje o biti univerziteta, naime kakav bi trebao biti te kakav bi morao biti njegov razvoj u budućnosti. Dakle to jest programatski govor kojim se zacrtava smisao budućeg "samopotvrđivanja” njemačkog univerziteta, ${ }^{13}$ ali on ne sadrži nikakav konkretan program univerzitetske reforme. U njemu je riječ o povijesnoj biti ljudskog odnosa prema znanosti odnosno porijeklu tog odnosa te njegovog "početka" u osvitu "grčke filozofije. U njemu zapadni čovjek po prvi puta ustaje iz jednog naroda snagom svoga jezika protiv bića u cjelini i propituje ga i shvaća kao biće, koje ono jeste." ${ }^{14}$ U govoru je dalje riječ o tomu što bi jedan preobraženi univerzitet, dakle jedno visoko učilište koje živi iz obnove "početka naše duhovno-povijesne egzistencije" trebalo konstituirati. Kao u nekom iskrivljenom ehu Platonovih idealnih stratifikacija utopijske države Heidegger tu navodi buduću ukorijenjenost studenata u "radnu službu", "obrambenu službu" i "službu znanja". Tu se vidi da Heidegger nastoji svoje filozofske postavke pretočiti u zbilju. ${ }^{15}$

Cijela konstrukcija budućeg "njemačkog”, dakle nacističkog univerziteta međutim ovisi o presumpciji njemačke volje za njim. Tako je velik dio govora posvećen toj volji - koja treba biti, koju treba probuditi, slijediti; zapravo koju Heidegger naslućuje, a u biti je njegova fantazija: povukla ga je - dalo bi se nagađati - ta nacionalistička euforija i uzbuđenost, to njemačko "događanje naroda" koje mu se prividjelo kao jedno sveobuhvatno raspoloženje za temeljni preobražaj u bliskosti s onim što je on misaono priredio. Govor ostaje na tom zazivanju sveopće volje, a naročito volje mladih kao temelja za istinsko utemeljenje univerziteta $u$ znanju. "I znanost $i$ njemačka sudbina moraju ujedno doći do moći u volji biti". " ${ }^{16}$ Apelativni karakter govora dolazi posebno do izražaja kad je riječ o vraćanju na "grčki” početak, odnosno o obnavljanju tog početka.

Što Heideggerov "Osvrt" nudi kao odgovore na bitna pitanja njegovog upuštanja u rektorsku avanturu? Brzo postaje jasno da se posebice centralni pojam i funkcija volje tog i drugih programatskih tekstova tog perioda uopće ne spominju. Heidegger dakle u svom osvrtu zanemaruje razmotriti jedan od najbitnijih elemenata kako svog govora tako i njegove intencije: projekciju volje, ali nabraja što je zapravo htio, a što nije.

Osim toga treba napomenuti da je taj Heideggerov osvrt - baš kao i drugi slični tekstovi objavljeni tek nakon njegove smrti - odmah po objavljivanju postao pred-

13 Ibid., str. 13.

14 Ibid., str. 7.

15 Dieter Thomä tendira isto takvom tumačenju u: "Heidegger und der Nationalsozialismus. In der Dunkelkammer der Seinsgeschichte", objavljenom u: Dieter Thomä (prir.), HeideggerHandbuch. Leben - Werk - Wirkung, Metzler, Stuttgart/Weimar 2005, str. 141-162, 145.

16 RG, str. 6. 
metom opsežnih ispitivanja i istraživanja. U njihovom središtu stoji pitanje o točnosti Heideggerovih navoda i tvrdnji odnosno o njegovoj blizini nacizmu. Akribične analize u velikoj mjeri pokazuju da se Heideggerov prikaz tadašnjih događaja ne poklapa s historijskim činjenicama te se uglavnom ne može uvažiti kao opravdanje. ${ }^{17}$ Pitanje je pak što su bile istinske Heideggerove namjere bez obzira na pokušaj opravdanja. Ono se ipak susreće sa sličnim problemima, naime Heideggerovim prikrivanjem istine. Odmah na početku osvrta on eksplicitno ukazuje na svoju glavnu namjeru citirajući uvodne rečenice iz prijašnjeg nastupnog predavanja "Što je metafizika?" iz 1929. g. kad je naslijedio Husserlovu katedru u Freiburgu:

Mi pitamo ovdje i sada, za nas. Naša egzistencija - u zajednici istraživača, nastavnika i studenata - je određena znanošću. ... rasuta raznorodnost disciplina ostaje danas još na okupu i održava se u jednom značenju jedino putem tehničke organizacije univerziteta i fakulteta te putem praktičnog određenja svrhe u strukama. Izumrla je nasuprot tomu ukorijenjenost znanosti u temelju njezine biti. ${ }^{18}$

Ove rečenice po Heideggeru iznose "zadaću" koje bi se univerzitet trebao prihvatiti, naime "izvornije" traženje "vlastite biti". Ali i ta zadaća i njegova namjera naznačene su indirektno, naime kao oštra dijagnoza stanja, čime se sugerira da ono vapi za promjenom; prešućeno treba dakle nadopuniti: ako je "ukorijenjenost znanosti u temelju njezine biti" "izumrla", treba ju dakle obnoviti, a to bi trebalo biti nešto posve drugačije od puke tehničke organizacije. Strateški, Heidegger prezentira ovaj citat kao dokaz da mu je pitanje univerziteta bilo važno i prije ikakvih naznaka dolaska na vlast nacionalsocijalista i dugo prije rektorata. Na tom tragu ono još neizgovoreno treba potražiti $u$ daljnjem tekstu tog nastupnog predavanja, koji on ovdje citira. Govor "Što je metafizika?" se može smatrati jednim od najkontroverznijih Heideggerovih tekstova. I on sam je u njemu unio neke prilično drastične izmjene. Napisao je također i jedan uvod za peto izdanje (1949) i jedan pogovor za četvrto (1943) koji su i sami bili predmetom preinaka. Te okolnosti su izazvale niz kritičkih reakcija, a mogle bi biti predmetom dizertacija.

U raščlanjivanje tog izazovnog teksta se neću upuštati, tek toliko: opći karakter teksta je, slično rektorskom govoru, po stilu programatski te se može zaključiti da mu je i služio kao podloga. Naročito je stil indirektnih poruka gotovo identičan. Središnja linija izlaganja ukazuje na ono što znanost nije i ono što je izvan horizonta znanstvenih istraživanja, dakle ono što znanosti ne samo da nisu i ne mogu biti nego ono što

17 Naročito temeljita istraživanja je na freiburškom univerzitetu poduzeo Bernd Martin. Usp. moje napomene i literaturu uz RG, str. 105.

${ }_{18} \mathrm{RG}$, str. 17. Inače Heideggerovi kritičari polaze od datosti univerziteta kao takvog i ignoriraju ono što on određuje kao cilj: "ukorijenjenost znanosti u temelju njezine biti”; za kritičare kao znanstvenike bit znanosti naravno nije nikakvo znanstveno ni univerzitetsko pitanje. Međutim ono je to bilo za Heideggera, pa ga se ne bi smjelo sasvim ignorirati. 
one ni neće da budu. Mogli bismo reći: Heidegger je na tragu onog drugoga univerziteta, međutim što je to, ostaje otvoreno. Aura tog izlaganja je zapravo prava, kompletna revolucija - i to ne samo u odnosu na realno postojeći univerzitet i ne samo na njemačku realnost znanosti nego u odnosu na cijelu zapadnoeuropsku duhovnost.

Jedino ako znanost egzistira iz metafizike, može ona uvijek iznova zadobivati svoju bitnu zadaću, koja se ne sastoji u sakupljanju i uređivanju znanja, nego u uvijek novom otvaranju cijelog prostora prirode i povijesti. ${ }^{19}$

Revolucija je u povratku izvorištu metafizike, ali kako viziju 'povratka početku' uopće programatski artikulirati u smislu obnove univerziteta i kako bi to bilo moguće iz pozicije rektora? Iznad svega iznijetog lebdi neki idealni zahtjev što bi se to trebalo fundamentalno preokrenuti, ali osim što je na kraju predavanja zamijenio svoj monološko-asertorički stil govorom u množini i naznačio moguću zajednost, Heidegger perspektivu nekog ozbiljavanja tog velebnog nacrta kompletnog preokreta konstitucije zapadnoeuropske duhovnosti ostavlja da zjapi otvorena. Tu je onda i naznaka kako bi trebalo početi s okretom ka korijenima metafizike:

Ako smo ovo izneseno pitanje o ničemu zaista supitali, onda metafizika nije bila dovedena izvana pred nas. Također se nismo tek uživjeli u nju. Mi se čak ni ne možemo u nju uživjeti jer u njoj već uvijek - ukoliko egzistiramo - i živimo. ${ }^{20}$

Je li taj "mi” imao opravdanja u konkretnoj stvarnosti? Nije poznato da je Heidegger s bilo kim bio u takvom "mi-zajedništvu" s kime bi "su-egzistirao u metafizici" odnosno osvijestio to egzistencijalno djelovanje. ${ }^{21}$ On se sada nalazi na toj superiornoj poziciji, ali oko njega nema nikoga tko bi s njim nosio taj projekt, nema sljedbenika ontološke revolucije univerziteta. Heidegger počinje usamljen i ostaje usamljen.

19 "Was ist Metaphysik?", Frankfurt $1975^{11}$, str. 41.

20 Ibid., str. 42.

${ }^{21}$ Sudeći po prepiskama, najintenzivniji međuljudski kontakt Heidegger je imao s Karlom Löwithom $-u$ ranom periodu njihovog prijateljstva. Izuzetnim se čini iskrenost, otvorenost $\mathrm{i}$ dubina njihove razmjene mišljenja, ali i uzajamne kritike, te savjeti i međusobna podrška i ohrabrivanja. Bez daljnjeg tu je i iskrena briga jednog za drugog, naročito Heideggerova za svog učenika koji živi kao student u raznoraznim, ne samo financijskim ovisnostima. Takva isprepletenost egzistencijalnih problema s raspravljanjem o nekim od najbitnijih filozofskih pitanja je rijetka, a meni se čini i izuzetnom. Ova asocijacija mi se nameće vezano uz spomenute Heideggerove rečenice, iako to nije ono što on tu ima pred očima. Vjerojatno on karakteru tog prijateljstva nije posvetio nikakvu pažnju, a naravno da ni Löwitha ni bilo kog drugog od svojih židovskih učenika i učenica nije imao pred očima zazivajući su-pitaoce među poletnim studentima. Njemu su pred očima lebdjeli neki imaginirani njemački mladići, entuzijastički nacionalsocijalisti kao pregaoci bitka i sljedbenici njegovog mišljenja koje fundamentalno prekopava same temelje. MH/Karl Löwith, Briefwechsel 1919-1973, prir. Alfred Denker, V. Karl Alber, Freiburg/München 2017. 
Međutim on stalno - hipotetski - računa s nekim zajedništvom. To je izrazio glagolom "mitfragen"; ovaj dio složene rečenice je formuliran u pasivu, tako da "pitanje o ničemu" ostaje dominantan subjekt i uključuje pretpostavljene suaktere supitanja. Teško je međutim povjerovati da je netko od slušatelja tog inauguralnog govora to pitanje zajedno s Heideggerom supitao..$^{22}$ Ali stil predavanja jasno odaje da njime vlada upućenost prema cilju, a cilj je radikalna promjena univerziteta. Njegova vizija vidi novo utemeljenje univerziteta kakvog nikad nije bilo. Heidegger kao da je zaboravio da se kod početka filozofskog pitanja koje su postavljali starogrčki mislioci ne može pozivati na neki praoblik univerziteta; to vrijeme nije poznavalo institucije visokog znanja, osim privatnih. Što bi tu bilo prikladno kao uzor?

Takav preobrat $\mathrm{u}$ nešto potpuno nepoznato smatra Heidegger mogućim ako za to postoji ogromna kolektivna volja; zapravo je uvjerenost $\mathrm{u}$ to vjerojatno glavni motiv za njegov iznenadni skok u političku praksu koja stremi realizaciji:

Ali mi sljedbeništvo ne trebamo tek buditi. Njemački studenti marširaju. [...] Iz riješenosti njemačkih studenata da izdrže njemačku sudbinu u krajnjoj nuždi nastaje volja za bit univerziteta. ... Sebi samom dati zakon, to je najviša sloboda. ${ }^{23}$

Volja njemačke omladine njemu se čini evidentnom. Pitanje je međutim čemu ta volja stremi? Dakle Heidegger u masovnom nacionalističkom pokretu mladeži i studenata - uz tada svima poznata divljanja i rasističko, antisemitsko nasilje - prepoznaje njihovu riješenost da izdrže njemačku sudbinu i smatra da tako izražena volja služi realizaciji njegove vizije drukčijeg univerziteta. Desni studenti su međutim bjesnjeli i divljali iz sasvim drugih pobuda. Univerzitet bi trebao tu volju prvo tesati i usmjeravati je bitnom znanju znanosti; zato ta visoka škola treba biti uređena na principu vođe, da bi se u njoj obrazovali "vođe i čuvari njemačkog naroda". ${ }^{24} \mathrm{U}$ jednostavnijem jeziku kojim stranim studentima objašnjava što je "njemački univerzitet" on predstavlja "nacionalsocijalističku revoluciju" već kao činjenicu; ona je već "počela", pripremljena "duhom fronta" nastalog "u ratu", što "univerzitetu" pruža ponovno "čvrsto tlo": "volja za odgojem ujedinjuje ponovno rad na univerzitetu u jednom novom temelju". U "tom novom zbivanju" nalazi se naš narod, o čemu "Führer ima sigurno znanje i neukrotivu volju". ${ }^{25} \mathrm{Na}$ tim (krivim) pretpostavkama je počivala njegova projekcija novog univerziteta.

${ }^{22}$ Uostalom iz prepiski i zapisa se može doznati da je Heidegger u sebi ipak u to sumnjao i uopće bio razočaran studentima. Usp. GA 94, str. 110, 116.

${ }^{23} \mathrm{RG}$, str. 10.

${ }^{24}$ Ibid., str. 8. Figura vođe (Führer) u Heideggerovoj nacionalsocijalističkoj koncepciji s pravom izaziva brojne kritičke diskusije. Zapravo ostaje nejasno u čemu bi ona uopće bila utemeljena. Volja treba vođu? usp. https://de.wikipedia.org/wiki/Martin_Heidegger_und_der_Nationalsozialismus.

${ }^{25}$ GA 16, str. 301-302, 306-307. 


\section{O "zabludi rektorata"}

Ne čudi da je on kasnije tu svoju eskapadu nazvao svojom "najvećom glupošću" ${ }^{26}$ U osvrtu iznosi činjenice iz vlastitog ugla, a kao odgovor na stvarna ili zamišljena iskrivljavanja svojih protivnika - zbog čega mu taj osvrt služi i kao obrana pred univerzitetskom komisijom (1945). Sad kad se slika o njegovom djelovanju i razmišljanju u to doba prilično zaokružuje, pokazuje se u kolikoj mjeri je Heidegger zataškavao bitne elemente te epizode, što otežava razumijevanje njegovih stvarnih poriva.

Objašnjenja što je s tim angažmanom htio dominiraju njegovim privatnim zapisima, a prisutna su i u prepiskama, iako više kao nagovještaj. Nakon objavljivanja zapisa 2015. uslijedilo je zasad zadnje veliko i očekivano skandaliziranje nad Heideggerovim "antisemitizmom" odnosno nacističkim opredjeljenjem. ${ }^{27}$ Radi se o zapisima u razdoblju od 1942. do 1948. pod naslovom "Napomene". Heidegger se i u njima opetovano vraća pitanju svog rektorata. On se baš i ne pita "što sam s tim zapravo htio", nego gdje je bila greška, što je krenulo krivo i (rjeđe) u čemu je bila "moja zabluda": Heidegger misli da je našao odgovor u tomu što je prenaglio sa svojom idejom. Dakle zabluda rektorata bi ležala u "preuranjenosti mog mišljenja" ${ }^{28}$ Tako je težište problema pomaknuto. Ne pita se: zašto, koji motiv, koja namjera, a kao drugo Heidegger ne dovodi u pitanje svoj koncept, dakle ne pita je li ideja takve radikalne promjene univerziteta, koja se čak uopće ne može nazvati reformom, kompatibilna sa stvarnošću te bilo kako provediva i sa kim. Ukratko, ne pita "je li moja ideja bila pogrešna”? Za njega ostaje neupitan taj revolucionarni koncept koji ništi samu institucionalnu bit univerziteta da bi se okomio na razne okolnosti - od nespremnosti okoline i kolega do krivog povijesnog trenutka - i tu nalazi razloge neuspjeha. Fundamentalni propust polovične kritičke samorefleksije bio je u nepostavljanju pitanja o ideji volje koja je bila okosnica kako vizije preuređenja univerziteta tako i motiva za njegov osobni angažman, a koju je poslije jednostavno napustio.

${ }^{26} \mathrm{Tu}$ izjavu navodi Heideggerov dugogodišnji poklonik H. W. Petzet; vidi opširnije o tomu: RG, str. 67 (napomene); u nedatiranim zapisima, a prema informaciji priređivača (Peter Travny), negdje između 1936. i 1938. Heidegger je zabilježio: "Velika greška tog govora je... da on još pretpostavlja da na prostoru njemačkog univerziteta postoji još jedan sakriveni rod pitajućih, da se on još nada da se njih može privesti radu na unutrašnjoj pretvorbi”, GA 94, str. 286.

27 GA 97, Anmerkungen I-V(Schwarze Hefte 1942 - 1948), prir. Peter Trawny, Frankfurt 2015, poznatije kao "Crne bilježnice". Usp. prikaz debate: Richard Wolin, "Heideggers 'Schwarze Hefte'. Nationalsozialismus, Weltjudentum und Seinsgeschichte”. Die Heidegger-Debatte, Vierteljahrshefte für Zeitgeschichte, juli 2015, tom 63, broj 3, str. 379-410. U tom zgražanju se i malo pretjeruje, primjećuje Holger Zaborowski, usp. H. und der Humanismus, H.-Jahrbuch 10, prir. A. Denker/H. Zaborowski, Freiburg/München 2017 i Südkurier 23. lipnja 2015.

${ }^{28}$ GA 97, Anm. II, str. 130; slično: “... pogreška 'rektorata 1933'... što sam mislio, sad je došlo vrijeme, ne s Hitlerom, ali s buđenjem naroda da u svojoj zapadnoj sudbini postane početan povijestan. ... Pogreška je bila u prenagljivanju [u vremenu]... da [ono treba] 'dugo' da se preokret ne može stvoriti ‘djelovanjem' i jednim ‘udarcem'”, str. 98. 
Tu se pokazuje tipično preispitivanje savjesti na pola puta, koje naime staje pred otvaranjem najbolnijih pitanja. Ne želim se upuštati u daljnja psihologiziranja, no želim reći samo da se radi o tipičnoj strukturi narcisoidnih ličnosti, koje nisu sposobne za zrelu i iskrenu samorefleksiju. Posljedica toga je da se ne postavljaju prava pitanja; to je šteta, jer iskreno suočavanje s vlastitim greškama Heideggeru bi vjerojatno donijelo pravo olakšanje, a i druge koristi. ${ }^{29}$ Objektivno gledano, bilo bi temelja za drukčiju kritičnu samorefleksiju polazeći od onog dijela silnog materijala Heideggerovog djela koje je realističnog karaktera, a posebice od njegove plodne djelatnosti kao predavača i učitelja. Struktura njegove refleksije ga je gurala u grižnju bez katarze, pa se tako stalno vraćao toj traumi i njenom epilogu "izbacivanja s univerziteta". ${ }^{30} \mathrm{Kad}$ se pogled pak uperi na zapise koji zrcale njegove životne stavove, pogled na svijet, političke ocjene i procjene i vrijednosni sustav, ipak je teško zamisliti neku drugačiju samorefleksiju. Nazovimo to Heideggerovim unutrašnjim svijetom; taj njegov "unutrašnji svijet" je čista, kompletna zatvorenost. To se naročito ogleda u tim "Crnim bilježnicama" i to već kroz činjenicu da se u svim tim silnim zabilješkama ne pojavljuje nitko osim njega samog: nema prijatelja, bližnjih, sugovornika bilo kojeg tipa. ${ }^{31}$ To je teško prihvatiti kod jednog filozofa čije mišljenje je posvećeno otvorenosti, traganju za omogućujućim dimenzijama onog otvorenog (das Offene) i neuhvatljivom biti horizonta. ${ }^{32}$ Međutim to je činjenica, i to činjenica koja pokazuje jedan začuđujući paradoks, gdje za dvije strane Heideggera kao čovjeka i osobe nema nikakvog pomirenja. Njegove refleksije o pogrešci kod rektorata se jedva dotiču biti problema. Pokazalo se da on sam koncept ne dovodi u pitanje niti reflektira pretpostavke svojih projekcija - odnosno "sna" (Safranski) - iako mu je zapravo moralo postati jasno da se taj njegov radikalni koncept ne može pomiriti ni s kakvom formom univerziteta. ${ }^{33}$

${ }^{29}$ Za života je Heidegger najviše bio napadan zbog svoje šutnje.

30 Ibid., str. 74.

31 Nije čudo da u tobožnjim "dijalozima” (Feldweg-Gespräche) Heidegger izmišlja neke tobožnje sugovornike: mudraca, istraživača, naučnika, Japanca. Otvorenim, iskrenim, povjerljivim i razgovorljivim Heidegger se pokazuje u nekim prepiskama (sa svojom ženom, s Hannah Arendt, Löwithom i Bultmannom).

32 Ta kategorija je na neki način konstanta u Heideggerovom mišljenju, a eksplicitno je kao takva potvrđena i u kasnijem periodu, dakle nakon poznatog "okreta" (Kehre), gdje je i na nov način produbljena: GA 77, Feldweg-Gespräche (1944/45), (Erdachte Gespräche), prir. Ingrid Schüßler, $2007^{2}$, str. 91, 112 \& passim. U toj tzv. kasnoj fazi, čija bitna karakteristika je odustajanje od bilo kakvog transcendentalnog utemeljenja, upravo "otvorenost" (die Offenheit) stupa na mjesto utemeljujućih funkcija transcendentalnih omogućavanja, s tim što Heidegger nastoji oko toga da iz svoje semantike ukloni konotacije proizvođenja, uzrokovanja, učinka, ukratko volje i onog tehničkog.

${ }^{33}$ Konzekvence su za njega "kraj univerziteta", "trebamo jedan novi ustav univerziteta... k uništenju univerziteta", "smrt univerziteta", GA 94 ("iz vremena rektorata"), str. 111, 115, 125. 


\section{Heideggerovi studenti}

Heidegger je imao mnogo učenika, a naročito mnogo onih uspješnih, od kojih je većina napravila zapaženu akademsku karijeru. Hans-Georg Gadamer, Hans Jonas i Karl Löwith su kao studenti bili u bliskom kontaktu međusobno i u različitoj mjeri s Heideggerom. ${ }^{34}$ Oni nam u raznim tekstovima i biografskim zapisima prenose društvenu i političku atmosferu tog vremena u mjestima Heideggerovog djelovanja - Marburgu i Freiburgu. Ništa u tom okružju ni u tragovima nije blisko s reakcionarnim, nacionalističkim pokretom tog vremena. Gadamer, koji je nadživio sve sudionike tih događanja, naročito je dobar i izdašan svjedok tog vremena. ${ }^{35} \mathrm{Tu}$ se ne može govoriti o nekoj grupi: od Heideggerovih - uvjetno rečeno - učenika Leo Strauss s jedne strane postaje izrazito konzervativan, antimodernistički nastrojen politički filozof, dok Hans Jonas, a naročito Herbert Marcuse zastupaju lijeve, marksističke pozicije. Uostalom Heidegger nije ustanovio neku svoju "školu". Jedino što njih evidentno povezuje jest da njihovo djelo ne bi bilo takvo kakvo jest bez utjecaja koji su doživjeli studirajući kod Heideggera. To je naravno uvelike slučaj kod Hannah Arendt, koja je, kao što je poznato, bila više od učenice. Nitko od njih prije nacističkog osvajanja vlasti nije upozorio na Heideggerove sklonosti nacizmu. Također, nitko iz kruga njegovih učenika i suradnika nije poznat kao prononsirani ideolog nacizma ili širitelj rasističkih i nacističkih ideja, a naročito ne kao istaknuti funkcionar nacističkog režima. Oskar Becker, koji je neko vrijeme zajedno s Heideggerom bio asistent kod Husserla i pripadao širem krugu "učenika", bio je poklonik rasističkih ideja koje su bile i sastavni dio njegovog teorijskog diskursa. ${ }^{36}$ Tom širem krugu je pripadao i pedagog Otto Friedrich Bollnow, za kojeg se može reći da je bio "pravi nacist", član NSDAP-a i SA od početka. Najintenzivniji njegov kontakt s Heideggerom je bilo protokoliranje slavne dispucije s Cassirerom 1929. g. u Davosu. ${ }^{37}$ Kod Lea Straussa je zamjetan utjecaj Heideggerovog "grčkog” mišljenja, te je on jedan od rijetkih (uz Hannah Arendt) iz te generacije koji je impetuse starogrčkih izvora integrirao u svoju političku filozofiju - s tim da se on već prije bavio antikom. Strauss je također bio cionistički aktivist i poklonik antiliberalnih teza "političke teologije" Carla Schmitta. Zagovarao je povratak političke filozofije na predmoderne temelje ili bolje pred-hobbesovske u obliku antičkog prirodnog prava.

34 O tim odnosima vidi odgovarajuće članke u Heidegger-Handbuch.

35 Hans-Georg Gadamer, Philosophische Lehrjahre, Frankfurt 2012 ${ }^{3}$. Sin Hermann Heidegger ističe da njegov "otac nije imao ni jednog učenika koga bi se moglo nazvati nacionalsocijalistom”, GA 16, str. 835.

36 https://de.wikipedia.org/wiki/Oskar_Becker_(Philosoph).

37 Safranski, str. 221; usp.: https://de.wikipedia.org/wiki/Otto_Friedrich_Bollnow. Upada u oči da je Bollnow s tom svojom nečasnom prošlošću mogao bez problema nastaviti univerzitetsku karijeru poslije rata. 
Njegova politička filozofija je eksplicitno jedan protuprosvjetiteljski projekt. Ovdje se ipak prije može govoriti o nekoj konvergenciji političkih stavova nego o direktnim uplivima. ${ }^{38}$ Ali zapravo su to iznimke, jer većina osoba iz Heideggerovog kruga prije 1933. g. nije bila konzervativno orijentirana, a i ako su bili, svejedno nisu podupirali nacizam i Hitlera. Razlog tomu je evidentan: senzacionalna predavanja Heideggerova zračila su blistavim sjajem modernosti, predstavljala su vrhunac novog filozofiranja u Njemačkoj i zato su privlačila studente u potrazi za naprednim mišljenjem i shvaćanjem svijeta. Bila je to glad za promjenom, a Heidegger je ocrtavao nuždu fundamentalnih promjena u pristupu najbitnijim, ontološkim problemima, situirajući ih istovremeno tu i ovdje, u ličnoj egzistenciji, "fakticitetu" i prosječnoj svakodnevnici. Bio je avangardna ekspresionistička pojava, a posjedovao je u svojoj performativnoj odlici pred slušateljima očitu snagu sugestivnosti. ${ }^{39} \mathrm{Njegova}$ osobena modernost, kojoj je ipak nedostajalo karakteristično liberalno opredjeljenje, pruža ujedno i objašnjenje za nadprosječnu zastupljenost židovskih studenata u njegovim kolegijima. Židovske elite su generalno bile otvorenije prema modernim tendencijama, a obrazovana mladež tim više. To im je omogućavalo kolektivno iskustvo koje ih je učilo kompatibilnosti s društvenim promjenama većinskog društva, preoblikovanju i napuštanju tradicije, nužnosti prilagodbe, fleksibilnosti namjesto zatvorenosti u vlastiti naslijeđeni svijet. Uostalom i poboljšani građanski status Židova u njemačkom društvu je bio relativno nov i rezultat reformi. Dakle može se poći od generalno pozitivnog odnosa dobrog dijela židovskih zajednica prema reformama općenito, progresu, modernosti, novome, svemu što otvara nove mogućnosti i možebitno donosi neka daljnja poboljšanja. Takvim progresivnim duhom dišu Heideggerovi najbliži učenici kao što su Karl Löwith i Hannah Arendt, ali i mnogi drugi iz tog kruga. Međutim velika masa studenata je bila izrazito reakcionarno nastrojena, mnogi su bili organizirani u SA-trupe i krčili su put nacizmu na univerzitetima. ${ }^{40}$ Heideggerova predavanja i publikacije su u tim krugovima bili i predmet kritike. ${ }^{41}$

\section{Paradoks Heidegger: modernost nacističkog profesora}

U liberalnoj javnosti Heidegger je bio viđen kao kulturni reakcionar. ${ }^{42}$ Usprkos tomu njegova predavanja iz dvadesetih i početka tridesetih godina zrače modernošću, pa

38 O njegovoj karijeri u Sjedinjenim Državama usp. https://en.wikipedia.org/wiki/Leo_Strauss.

39 Gadamer, str. 24.

${ }^{40}$ Usp. Dunja Melčić, "Heidegger u svom dobu”, RG, str. 160 i d.

41 Safranski, str. 321, 326, 350; recimo ovim riječima: "njegova filozofija je očiti ateizam i metafizički nihilizam kakvog inače kod nas zastupaju uglavnom židovski književnici”.

42 Ibid., str. 249. 
i u publiciranoj formi. Za to nije potreban nikakav komplicirani dokazni postupak, jer Heidegger sam u predavanjima opetovano poseže za primjerima iz modernog svijeta i načina života te često reagira na aktualnosti društvenog i političkog zbivanja ne formulirajući vlastiti politički stav. Kad je 1923. i 1924. po centrima ruhrske oblasti držao predavanja (pod naslovom "Dasein und Wahrsein nach Aristoteles"), politička situacija tamo je bila izuzetno napeta, a Heideggerova fenomenološka deskripcija "prapolitičke svakodnevnice" kao "istoizvorne s ekonomskim i tehničkim sklopovima okoline" u kojoj dolazi do "sloma te nestanka onog poznatog", ustaljenog, može se shvatiti kao odgovor ili "diskretno komentiranje" aktualnih događaja, kako u jednom prinosu izlaže američki poznavatelj Heideggerovog djela Theodor Kisiel ${ }^{43}$ Središnji aktualni događaj tada je bilo strijeljanje nacionalističkog terorista Lea Schlagetera, koje je u okupiranoj ruhrskoj oblasti i šire izazvalo silne proteste. Ali nekog politički mirnog i stabilnog perioda u to doba u Njemačkoj nije ni bilo. Heidegger drži svoje prvo marburško predavanje u vrijeme tzv. minhenskog puča 8. novembra $1923 .{ }^{44}$ Dio predavanja se bavi fenomenologijom laži, poluistina, obmanjivanjem. Polazeći od Aristotelovih definicija laži, Heidegger ukazuje na novi vid lažnog govora, gdje je “'pravo vrelo obmane' u 'fakticitetu' govorenja kao takvom...” Propagandne laži su bile značajan dio uzavrele političke zbilje, utjecale su na zbilju i njenu percepciju, tako da razbistravanje fenomena laži nije bilo tek apstraktno teoretsko pitanje. Heideggeru uspijeva fundamentalnom opažanju fenomena podariti konotacije koje ga povezuju s aktualnom životnom situacijom:

Laž leži u fakticitetu govorenja... ona nosi u sebi još jednu temeljnu mogućnost obmanjivanja. Moguće je također jedno govorenje koje nema nikakav odnos prema stvarima... neodgovorno brbljanje koje je kao takvo opasnije od neke teške laži. Takvo lupetanje u prazno obmanjuje samim faktom... da se govori. ${ }^{45}$

Uostalom intrinzična sloboda jezika i govora dopušta $i$ zloupotrebu, iskrivljavanja i obmanu. Heidegger stvara kod svojih studenata dojam da moderna (fenomenološka) filozofija ima veze s vlastitim životima tu i sada, da se svakog životno tiče, a pronicanje tih fenomena i jezika laži omogućuje orijentaciju u kaosu političke propagande. Upravo tako on 1924. piše svom učeniku Karlu Löwithu: "mi se

${ }^{43}$ Kisiel, Theodore: "Heideggers Einsetzung der rhetorischen Politik in seine 'urpraktische' Ontologie (Die Franzosen besetzen das Ruhrgebiet, 1923-25), u: Metaphysik der praktischen Welt: Perspektiven im Anschluß an Hegel und Heidegger. Festgabe für Otto Pöggeler, prir. Andreas Grossmann..., Rodopi, Amsterdam 2000, str. 165-175.

${ }^{44}$ Hitler je u naletu htio preuzeti vlast i proglasio se "budućim predsjednikom i kancelarom Reicha”. Puč je već sutradan bio proglašen veleizdajom, a Hitler u bijegu uhvaćen i zatvoren.

${ }^{45}$ GA 17, Einführung in die phänomenologische Forschung (zimski semestar 1923/24), prir. Friedrich-Wilhelm v. Herrmann, Frankfurt 2006², str. 35. Usp. Kisiel. 
ne bavimo filozofijom da bismo zgrtali znanja i rečenice, nego da bismo oblikovali život". ${ }^{46}$ Međutim to je i varljivo, jer ako se tu nazire kritički stav prema lažljivom i propagandističkom govorenju ili huškanju poluistinama, za Heideggera taj nalaz - paradoksalno - nije povezan s najočitijim lažima nacista koje su u opticaju. Tako upada u oči izuzetno fenomenološko-hermeneutičko razjašnjavanje mogućnosti propagandističke laži i poluistine s jedne strane te Heideggerovo sljepilo za nacističku propagandu i laži s druge.

Taj Heideggerov “uvod u fenomenološka istraživanja” je senzacionalno štivo u kojem se zrcali živost i dojmljivost neposrednog predavanja. Njegovo analitičko i zorno izlaganje osnova Husserlovih istraživanja i njegovih ključnih pitanja na početku tih predavanja tada je bilo velik doprinos razumijevanju Huserlove filozofije uopće, a na to se tek nadovezuje ukazivanje na granice Husserlovog polazišta i njegove ovisnosti o preuzetim (zanemarenim) povijesnim temeljima.

Taj pristup odiše neupitnom filozofskom modernošću koja pokapa staru metafiziku. Pa i šest godina kasnije u kolegiju "Temeljni pojmovi metafizike", koji je držao u zimskom semestru 1929/1930. u Freiburgu, kad se posvećuje analizi, ekspoziciji i fenomenološkoj deskripciji dosade kao egzistencijalnog raspoloženja, Heidegger u tom svom slavnom i briljantnom izvođenju razrađuje jedan po svemu moderan način bitka. ${ }^{47}$ I sad se ponovno postavlja pitanje studenata: koga privlače takva predavanja, i to - kao što je poznato - u velikom broju? To najvjerojatnije nisu bili desni i nacionalistički studenti. ${ }^{48}$ Koliko znam, o tomu ne postoje odgovarajuća istraživanja pa se o karakteru publike mogu samo graditi pretpostavke. Stil predavanja odlikuje neposrednost kao da zaista nastaje zajednica filozofski pitajućih.

Evo jednog primjera iz Heideggerovog uvodnog epskog objašnjavanja dvosmislenosti filozofiranja:

Nas - vas kao slušatelje - neprestano opkoljuje i vreba jedno dvosmisleno biće: filozofija. A tek predavač - što on sve ne može dokazati... on može nastupati kao da filozofija kao apsolutna znanost s njim prvi put uopće dolazi na svijet... Je li on možda neki komedijant - tko to može znati?... Zašto on, ako je netko tko filozofira, napušta samoću i mota se kao javni profesor na sajmu?... Nagovaramo li na temelju nekog autoriteta, koji zapravo nemamo?... Jedino kad nismo shvaćeni, radi taj sumnjivi autoritet za nas. Kad smo pak shvaćeni, onda izlazi na vidjelo da

46 Heidegger/Löwith, Briefwechsel, str. 18.

47 Ti opisi podsjećaju na Joyceove rane epifanije svakodnevnice.

48 Nasuprot tomu na predavanjima (u ljetnom semestru 1934) najavljenima pod naslovom "Država i znanost" (Heidegger je promijenio temu u "logika") sala je bila puna smeđekošuljaša privučenih posebnim interesom nakon ostavke na rektorski položaj, a studenti su činili tek manjinu, v. Safranski, str. 328. 
li mi filozofiramo ili ne. Ako ne filozofiramo, urušava se taj autoritet sam od sebe. Ako pak filozofiramo, onda ga uopće nije nikad ni bilo. Tek tad će postati jasno da filozofiranje iz temelja pripada svakom čovjeku... Tako je svako filozofsko predavanje... dvosmisleni početak na način kako ga znanosti ne poznaju. ${ }^{49}$

Heidegger se u drugom dijelu predavanja nadovezuje na pitanja iz gore spomenutog nastupnog govora održanog pet mjeseci ranije ("Was ist Metaphysik?"), ali njihov stil je sasvim drugačiji od onog koji zvuči kao proglašavanje apodiktičkih istina. Zajedničko nastupnom predavanju u ljeto 1929. i redovitom kolegiju u zimskom semestru potom ipak je sporadični apelativni gest; to je između redaka zazivanje spremnosti za totalni preobrat, za iskakanje iz utabanih staza novovjekovnog bitka.

Tek još trebamo dozivati nekog tko našoj egzistenciji može utjerati strah. Jer kako stoji s tom našom egzistencijom kad je jedan takav događaj kao svjetski rat prošao pored nas bez bitnog traga $?^{50}$

Te rečenice mogu se interpretirati u smislu naznake afiniteta za nacionalsocijalističku revoluciju, iako Heidegger tada zazivanje preokreta u čovjekovom bitku, egzistenciji (Dasein) nije javno tumačio u nacionalnom smislu. ${ }^{51}$

Prvo objavljivanje tih predavanja 1975. posvetio je Heidegger sjećanju na Eugena Finka, naglašavajući njegovo intenzivno misaono učestvovanje na predavanjima. Fink je promovirao kod njega i Husserla. On se svakako nije pridružio Heideggeru u preoblikovanju "njemačkog univerziteta" uz pomoć nacističkog totalnog preuzimanja vlasti. Sasvim suprotno: Fink je u tom trenutku, 1933, odustao od daljnje univerzitetske karijere i podupirao kao privatni asistent Husserla koji je postao nepoželjan na univerzitetu, a nakon njegove smrti pomagao je u očuvanju i preseljenju njegove ostavštine u Belgiju. ${ }^{52}$ Je li Fink uočio naznake nacionalističke afilijacije $u$ Heideggerovim predavanjima? Vjerojatno je za Finka kao i za druge studente Heideggerov nacionalistički zaokret bio iznenađenje.

Njima je moralo biti blisko da Heidegger uz sve duboko propitivanje egzistencije i bitka otkriva kroz fenomenološku metodu gotovo sociološkim pogledom realni svijet života, svijet oko nas (Umwelt) s njegovim uporabnim stvarima (das Zuhandene, $\tau \grave{\alpha} \pi \rho \alpha ́ \gamma \mu \alpha \tau \alpha)$ u njegovom fakticitetu, što implicira shvaćanje udaljeno od nacionalističkog furora. I onaj preobratnički eros u spomenutom zazivanju egzi-

${ }^{49}$ GA 29/30, str. 18-19 (kurziv moj).

${ }^{50}$ Ibid., str. 254-255.

${ }^{51}$ Spomenuti privatni zapisi ipak sugeriraju da mu je intimno već tada to nacionalno shvaćanje bilo blisko.

${ }^{52}$ Za detalje vidi: https://de.wikipedia.org/wiki/Eugen_Fink. 
stencijalne pobune nije vjerojatno kod publike pobudio pomisao na političku revoluciju u smislu nacističke "Blut-und-Boden"-ideologije.

Dojam (pretpostavimo i kod neposrednih slušača tih predavanja) je neka mješavina ekstaze, ekscentričnog iskakanja iz svakodnevnice kao mogućnosti i pragmatizma te svakodnevnice, koja je egzistencijalna mjera u kojoj se prelamaju visokoparne apstrakcije na tu i ovdje.

To za što se on zalaže je neka druga filozofija (i drugi univerzitet) u čijem središtu su temeljna filozofska pitanja koja otresaju sa sebe balast tradicionalne metafizike, "kraljice" znanosti (koja uostalom već tada ionako nema tu poziciju), idealiziranu auru "prve znanosti". Vladajuću predrasudu - ili "nadripamet praznog sveznalaštva" - kako je "filozofsko znanje općenitije" i stoga "nadmoćnije" treba odbaciti, a znanost i "novija istraživanja" pratiti "filozofskim pogledom". Takav odnos između filozofije i znanosti je "odlučan za naš današnji univerzitet". ${ }^{33}$ Koliko se može naslutiti iz objavljenog, ta predavanja su odisala živom komunikacijom iako su naravno u biti bila monolog. U svemu tome se ne nazire neki stvarni povod za prijelomne akcije revolucije univerziteta. U načinu govorenja i držanja, cijeloj svojoj performativnoj pojavi dobiva se pak dojam da se on tu, u predavaonici, sa studentima i drugim polaznicima predavanja, ukratko na univerzitetu osjeća lagodno, reklo bi se: tu je doma.

Pretpostavimo li dakle iskustvo tih predavanja, bilo bi zamislivo da se netko upita ima li Heidegger sa svojim zahtjevima radikalne reforme univerziteta u vidu potrebu bolje komunikacije bez lažnih autoriteta, istinskog dijaloga između znanosti i filozofije, bolje protočnosti znanja? Zna se da mu to nije bilo u prvom planu, ako je uopće bilo u planu. Nameće se zaključak da je svoje prave ili intimne stavove zadržavao za sebe, zapravo ih uspješno prikrivao, ${ }^{54}$ da bi ih javno otkrio tek kad je smatrao da je za njih došao pravi trenutak.

Heidegger ne izaziva čuđenje zato što kao filozof simpatizira s jednim totalitarnim režimom; filozofâ sa simpatijama za apsolutnu vlast, sklonostima prema autoritarnosti, obožavatelja figure vladaoca (vođe) ima na sve strane. Čudi da on kao takav filozof najedanput javno pokazuje sklonosti nacionalizmu uopće..$^{55}$ Dojam nekog tko iskače iz univerzitetske konvencionalnosti kritičkim raskopavanjima nataložene tradicije i diferenciranim rastakanjem metafizičkog naslijeđa teško je povezati s dojmom osobe koja je u stanju nasjesti primitivnoj ideologiji jed-

53 GA 29/30, str. 280-281, 285.

${ }^{54}$ U zapisima nalazi se i dosta razmišljanja posvećenih mogućnostima reorganizacije univerziteta, tako (decembar 1933) i neki plan o fundamentalnoj političkoj nacifikaciji univerziteta $a ̀$ la Heidegger, GA 16, str. 130.

${ }^{55}$ Ali on je u stanju formulirati vrlo bitne karakteristike nacije koja "se postavlja za subjekt kojemu se sve objektivno priviđa jedino u svjetlu njegove subjektivnosti”, GA 77, str. 235. 
nog barbarsko-nacionalističkog pokreta ili ju svjesno prigrliti. Heidegger kao rektor freiburškog univerziteta i kao netko tko vjeruje Hitlerovoj plitkoj i preuzetnoj demagogiji krcatoj megalomanskim i nasilnim projekcijama, tko očekuje od njega i njegovog pokreta preporod njemačkog naroda, morao je negdje izgubiti svoj realizam i pragmatizam. To je istinski paradoks! Radi li se o prijetvornosti ili podvojenosti? Tu nema nečeg trećeg ili nadređenog u čemu bi se te dvije strane pomirile. Normalno bi se one nalazile na međusobno daleko udaljenim ekstremima, a ovako su se našle u jednoj osobi. Nakon što su objavljeni Heideggerovi nacistički govori i njegove privatne zabilješke, nema prostora za sumnju u to. ${ }^{56}$ To nespojivo u jednoj osobi ne sadrži u sebi nijednu naznaku nekog rješenja i ostaje zapravo zagonetka.

\section{Na pragu "totalnog preokreta"}

Čini se da Heidegger prvi put svoju naklonost nacionalsocijalizmu javno očituje u predavanjima o Platonu u akademskoj godini 1931/1932. ${ }^{57}$ Privatna svjedočanstva pružaju snažne indicije: Hermann Mörchen posjetio je Heideggera u to vrijeme za zimskog raspusta u njegovoj slavnoj kolibi u Schwarzwaldu, točnije mjestu Todtnauberg, i bio zaprepašten zapazivši Heideggerove očite simpatije za nacionalsocijaliste. O tomu svjedoči i Max Müller. ${ }^{58}$ Mörchen je tada bio Heideggerov student, a decenijama poslije priređivač izdanja tih predavanja. ${ }^{59}$

Tekst predavanja o Platonovoj Državi zahtijevao bi opsežnu, detaljnu interpretaciju. Bez potrebne analize i egzegeze neka mi ipak bude dozvoljen jedan dojam: Heidegger u njima kao da pravi mali eksperiment à la: "kako bi mogao izgledati

${ }^{56}$ Usp. Wolin. Te bilješke (die "Schwarzen Hefte") Wolin karakterizira kao "antiphilosophisches Traktat" odnosno "Anti-Traktat", "polemiku protiv razuma, individualizma, demokracije" i "kritiku besciljnosti njemačkog univerziteta u njegovom tradicionalnom liberalnom humboldtovskom otjelovljenju", str. 394.

${ }^{57}$ Safranski, str. 268.

${ }^{58}$ RG, str. 41 i d. Usp. također: https://de.wikipedia.org/wiki/Martin_Heidegger_und_der_Nationalsozialismus. "Tamo se navodi i Jaspersovo poznato prisjećanje (iz njegove autobiografije) na susret iz tog doba. Na njegovo čuđenje povodom "Heideggerovog pristupanja NSDAP-u", jer 'kako jedan tako neobrazovan čovjek kao Hitler može vladati Njemačkom?', Heidegger mu je "odgovorio 'obrazovanje je potpuno svejedno, pogledajte samo njegove predivne ruke!' [...] bio sam zbunjen. Heidegger mi ništa nije spomenuo o svojim nacionalsocijalističkim nagnućima prije 1933." Iz prepiski je poznato da je Heidegger vrlo kritički prosuđivao gotove sve ljude iz svoje okoline, zamjerao svojim kolegama pa i prijateljima raznorazne sitnice, bahato prigovarao svemu i svačemu - te ne zna grčki, te nema pojma o skolastici, ne zna misliti...; u slučaju Führera ga pak u njegovoj strastvenoj naklonosti ništa nije moglo pokolebati. To što Hitler ne zna grčki nema veze kad ima takve ruke! To se zove "prava ljubav"!

${ }^{59}$ Safranski, str. 268. Za Heideggera je uoči dolaska nacista na vlast "nastupio veliki trenutak povijesti, onaj preobražaj cijelog ljudskog bitka"; usp. GA 34, str. 78. 
izlazak iz pećine u političku realnost?" To je filozofiranje nad pitanjem kako prenijeti takvo znanje o "bîti čovjeka" koje "se ne može nikad znanstveno dokazati", a opet ne može se ni jednostavno "prihvatiti na osnovu nekog autoritativnog izričaja". ${ }^{60}$ Dakle tu su filozof koji je izašao iz spilje neznanja s jedne i zarobljenici u njoj koji sjenke drže za realnost s druge strane. Heidegger žonglira s idejom o fi-

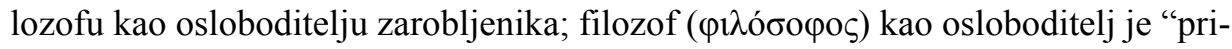
jatelj bitka". Ako ne može znanstvenim metodama, onda treba filozofski pobuditi ("zapaliti") i ishoditi bitak-razumijevajuće pitanje i tu upitnost bića u cjelini pretvoriti iz temeljne odluke u temeljno držanje. "Što to znači, o tomu ne treba dalje govoriti, to treba jednostavno činiti." Da li Heidegger time najavljuje svoj ulazak u politiku? On dalje govori o "granici", dakle recimo o nečem što činom postaje zbilja - ili ne. U tom međuprostoru je "ništa" ${ }^{61}$ To navodi na pomisao da tim razigranim tumačenjem Platonovog dijaloga kao da isprobava mogućnosti ulaska u politiku. Jedna od njih sadrži i opasnost da se bude ubijen. Heidegger onda faktičnu Sokratovu smrt upotrebljava kao metaforu za moguću sudbinu filozofa koji se osmjeli vratiti se u spilju da oslobodi zarobljenike opsjene prenoseći je u konkretnu suvremenu situaciju. To otprilike podrazumijeva da danas zbog filozofskog prosvjećivanja ili iznošenja istine nitko ne biva natjeran na ispijanje otrova odnosno nije životno ugrožen, ali može biti izložen opasnosti da postane "beznačajan i lišen moći", završavajući tu etapu egzegeze patetičnom tvrdnjom "sudbinu ove smrti u spilji nije još nijedan filozof izbjegao". ${ }^{62} \mathrm{U}$ predavanju ima mjesta i za ironiju: "Nije da profesori filozofije trebaju postati Reichs-kancelari". ${ }^{63}$ Dobrih godinu dana prije nacističkog preuzimanja vlasti Heidegger reflektira pred studentima razne mogućnosti smisla Platonove idealne države pod vodstvom filozofa svojim poznatim načinom: diferencirano, kopajući pitanjima sve dublje u fenomene, vadeći suptilne aspekte na svjetlo dana sukladno svom metodskom fenomenološkom credu "formalnog oglasa" ${ }^{64}$ i završavajući u otvorenom, zapravo spremnom za nastavak, za daljnja propitivanja.

Ali u intimnim zapisima iz 1931. i 1932. bilježi svoja očekivanja novog "doba" koje se najavljuje riječima "narod", "svijet u pregradnji”; ona ga vode poletnoj misli: "Jedino Nijemac može ponovno izvorno pjevati bitak". ${ }^{65}$ Te zabilješke su inače prožete potpunom negativnošću - protiv svega i svakog. Onda najedanput tu
${ }^{60}$ GA 34, str. 78.
61 Ibid.
62 Ibid., str. 84.
${ }^{63}$ GA 34, str. 100.
64 GA 29/30, str. 425.
65 GA 94, str. 26, 27. 
je raspjevano oduševljenje omladinom, njemačkošću, Führerom, narodnom voljom - koja se "krasno razbuđuje usred velike svjetske tame". Kao krivo odsviranom trubom zvuče ta ushićenja osvitom novog doba u kojem je Heidegger očekivao svakojaka čuda, između ostalog "narod" koji će čuvati "bitak". ${ }^{66}$ Jezični stil tog oduševljenja je isti kao i druge zabilješke: apodiktičke tvrdnje, sudovi i presude - skepsi i propitivanju ni traga. Dakle to je jedan drugi stil od onog jezika kojim Heidegger govori kad predaje na univerzitetu.

\section{Preokret gramatike: Heideggerov nacionalsocijalistički diskurs u komparaciji}

Tako se i Heideggerov politički diskurs svojom gramatikom uočljivo razlikuje od njegovog uobičajenog stila, ali sliči semantici iz intimnih zapisa. Politički govori kao da pripadaju jednom drugom jezičkom sistemu. Tu je i novi vokabular rektoravođe: uz originalne (razvodnjene) izraze svoje filozofije on se služi izrazima i pojmovima koji bi se ranije smatrali gotovo nezamislivim: sljedbeništvo, poslušnost, služiti, stega, vođa. ${ }^{67}$

Zamislimo da je mjesto slavnih marburških predavanja o dosadi kao egzistencijalnom raspoloženju par excellence Heidegger raspredao o očitovanju “prirode... kao prostoru naroda, kao krajobrazu i zavičaju, kao temelju i tlu... ona se oslobađa kao moć i zakon... naslijeđa" ${ }^{68}$ Tko zna koliko bi to privlačilo njegove tadašnje studente?

Uz već uobičajene izraze "odlučan”, "odlučnost” i "odlučenost" Heidegger sve češće upotrebljava izraz "volja", ${ }^{69}$ koji u nacističkoj fazi njegovog govora zauzima dominantno mjesto, kao uostalom i u nacističkoj propagandi samoj. Te riječi se u nekim istraživanjima nazivaju "ideologische Signalwörter", dakle riječi kao ideološki signali nacističkog režima, ali pojam "volja" dobiva za Heideggera funkciju magične riječi. Tek u svom postnacističkom (ili prijelaznom) periodu on se tematski kritički bavi tim pojmom kroz razračunavanje s Nietzscheovom metafizikom i pojmom "volje za moć", ali ne i sa svojom prijašnjom uporabom riječi.

Volji pak on u pravilu pridružuje i pojam "narod". U govoru za izbore novembra 1933. na kojima se moglo jedino zaokružiti “da" za "Hitlerovu listu”, Heidegger

\footnotetext{
66 Ibid., str. 98.

67 Tako prva rečenica proglasa "Deutsche Studenten!” (“Njemački studenti!”) iz oktobra 1933. glasi: "Nacionalsocijalistička revolucija donosi potpuni preobrat naše njemačke egzistencije (Dasein)", GA 16, str. 184.

68 Ibid., str. 200.

${ }^{69}$ Patrick Unruh, Register zur Martin Heidegger Gesamtausgabe, Frankfurt am Main 2017.
} 
podržava Hitlerov zahtjev za izlaskom iz Lige naroda ${ }^{70}$ jer glasovanjem "narod ponovno stječe istinu o volji svoje egzistencije...". ${ }^{71}$ Što je Heidegger sve poučavao o istini (die Wahrheit, A- $\lambda \hat{\eta} \theta \varepsilon ı \alpha$ ), da bi u poslušnom glasanju po vođinoj naredbi pronašao da "je istina otvorenost onoga što jedan narod čini sigurnim, bistrim i snažnim u njegovom djelovanju i znanju". ${ }^{72}$ Što se tu naziva "narod" (Volk)? Neki homogeni kolektivitet, neki grupni subjektivitet pod vodstvom jednog Vođe? Dieter Thomä, temeljiti poznavatelj Heideggerovog djela, konstatira da se pojam pojavljuje bez ikakvog izvođenja i utemeljenja. ${ }^{73}$ Prigrlivši "narod" Heidegger si je navukao mrenu na oči i nije u stanju uočiti da kada svi kao jedan glasaju po naredbi vođe, to odgovara analitičkom nalazu i kritici fenomena koji je on vodio pod nazivom "das Man":

Ova uzajamnost rastvara u potpunosti vlastiti tubitak u načinu bivanja "onog drugog", i to tako da ovi drugi još više nestaju u svojoj razlikovnosti i izrazitosti. U toj neupadnosti i neutvrdivosti razvija ono "se" [das Man] svoju pravu diktaturu. ${ }^{74}$

Te riječi bi mogle biti kritika javnosti i društvenog stanja u Hitlerovoj diktaturi, ali nisu; one su iz 1927, iz Bitka i vremena. Dakle diktatura javnosti, onoga "što ljudi misle", kako se osjećaju u masi i što im nešto znači ili ne znači u toj uniformiranosti, bezrazličnosti, nešto je što Heidegger detektira u weimarsko doba, koje u političkom smislu ima još kakvu-takvu demokratsku i liberalnu konstituciju prije Hitlerovog dolaska na vlast. To je fenomen prosječnog mnijenja gdje svi gledaju na stvari na neki neutvrđeni isti način, koji Heidegger naziva substantivirajući neodređeni pronomen "man" u "das Man"; das Man označava uniformnu javnost kao devijantni modus fundamentalno-ontološkog su-bitka (Mit-Sein) pri čemu Heidegger taj su-bitak drži jednako izvornim kao i tu-bitak (Da-Sein). S tom problematikom se Heidegger bavi još u temeljnoj ontološkoj analizi međusobnog ili uzajamnog ljudskog bitka u predavanjima iz zimskog semestra 1929/1930. "Ja" kao dominantno polazište je zapravo utvara,

privid na kraju još osnažen putem filozofije tako što je ona počela s dogmom po kojoj je pojedinačni čovjek nešto za sebe kao pojedinac, a pojedinačni “ja” je sa svojom ja-sferom ono što mu je samom nadomak i prvo i najizvjesnije dato. Tako se filozofski sankcionira mišljenje kao da neko "biti zajedno" tek mora biti stvoreno iz ove solipsističke izolacije. ${ }^{75}$

${ }^{70}$ Usp.: http://www.spiegel.de/einestages/75-jahre-machtergreifung-a-948018.html.

71 GA 16, str. 191.

72 Ibid.

73 Dieter Thomä, Die Zeit des Selbst und die Zeit danach. Zur Kritik der Textgeschichte Martin Heideggers, Suhrkamp, Frankfurt a.M. 1990, str. 554.

${ }^{74}$ Sein und Zeit (SZ), str. 126-127.

75 GA 29/30, str. 302, on se referira na SZ, $§ 25$, str. 114 i d. te $\S 64$. 
Međutim tu se pojam "naroda" još nigdje ne upotrebljava. A u Bitku i vremenu (§ 74) Heidegger na jednom jedinom mjestu spominje pojam "narod":

Ako tubitak koji ima sudbinu bitno egzistira kao bitak-u-svijetu u subitku s drugima, onda je njegovo zbivanje jedno su-zbivanje i određeno kao kob (Geschick). A time nazivamo zbivanje zajednice, naroda. ${ }^{76}$

To zbivanje Heidegger povezuje s odlučnošću (u poglavlju o povijesnosti $\S 74)$ : “odlučnosti" tubitka "da otvara pojedine faktičke mogućnosti istinskog egzistiranja iz naslijeđa, koje on kao bačeni preuzima". ${ }^{77}$

Bliskost je nepobitna: povijesno svjesno (i odlučno) egzistiranje crpi iz naslijeđenog svoje mogućnosti, što odgovara Heideggerovom konceptu "bačenosti" (Geworfenheit), jer je naslijeđe dio datosti u koju je čovjek (kao tubitak) bačen, ali razlika se doima ogromnom. Može li se ipak to mjesto interpretirati kao konstrukcija u zapećku? Odlučna bi bila u tom slučaju ona predodžba odluke za kob, preuzimanje na sebe moći sudbine, dakle konstrukcija koja iz bezlične mase rađa "narod" kao sudbinsku zajednicu. U toj konstrukciji "pravog i nepravog odnosa spram naroda" vlada dvoznačnost, dvosmislenost i to tako da jedno može izgledati kao drugo. ${ }^{78}$ Ono što po Heideggeru tu situaciju mijenja je volja, odlučenost za određene mogućnosti koje znače prihvaćanje vlastite sudbine i vode pravom zbivanju egzistencije, tubitka odnosno u ovom slučaju naroda. ${ }^{79}$

Pojam "sudbina" (Schicksal) za njemačke je intelektualne elite u prvoj polovici 20. stoljeća bila magična riječ. Patriotska propaganda njegovala je naročito u Prvom svjetskom ratu sintagmu "Schicksalsgemeinschaft", sudbinske zajednice, pa se ni slavni racionalni Max Weber nije ustručavao upotrebljavati ju. Predrasuda o nekoj nacionalnoj sudbini je dugo bila duboko ukorijenjena i široko rasprostranjena.

I za Heideggera je pojam sudbine (ili kobi) u ranom periodu posebna riječ i pojavljuje se isto kao s njom povezani pojmovi odlučnost, riješenost i nešto kasnije volja kao neki deus ex machina; oni u suptilnim i diferenciranim fundamentalnoontološkim i fenomenološko-hermeneutičkim analizama djeluju kao strano tijelo, kao neko odnekud zalutalo decizionističko zazivanje. S Heideggerovim opredjeljivanjem za nacionalsocijalizam oni - kao i pojmovi (njemački) narod, borba, država, stega - potiskuju fenomenološko razumijevanje svijeta i rezultate do kojih je došao analizom su-bitka i hermeneutičkom kritikom konformističkog masovnog ponašanja i držanja javnosti. Te negativno obojene načine egzistiranja u zajednici nije pre-

${ }^{76}$ SZ, str. 384.

${ }^{77}$ Ibid., § 74, str. 383.

${ }^{78}$ Ibid., str. 173 (“Zweideutigkeit").

${ }^{79}$ Ibid., str. 384-385. 
poznao u nacionalnom "pokretu" iako su tu bili puno izraženiji; rezultati izbora za koje je i sam tako svesrdno agitirao su bili ekstremni dokaz jednoumlja. ${ }^{80}$ To je bilo moguće zato što je za Heideggera to bila istina.

Dublje jezičke analize diskursa s filozofskom tematikom i političkih govora bi mogle pokazati da je on živio u dva svijeta. Heidegger koristi dva tipa diskursa; djelomično se to da poduprijeti i registarskim pregledom uporabe riječi: u Bitku $i$ vremenu izraz "narod" se nalazi jedan put, kao što je gore spomenuto; u predavanjima prvi put u zimskom semestru 1928/1929. (GA 27) i poslije sporadično, a u predavanjima SS 1933. i WS 1933/1934. i 1934/1935. vrlo često, pa onda (do 1944) jenjava na sve rjeđe. Međutim u neobjavljenim svakovrsnim spisima (zapisima, predavanjima, razmišljanjima) između 1936. i četrdesetih godina, a naročito u intimnim zabilješkama u tzv. Crnim bilježnicama (GA 94) pojavljuje se nakon 1931. nebrojeno puta. ${ }^{81}$ Pojam naroda (Volk) stupa - bez ikakvih utemeljenja ili kritičkih izvođenja - na mjesto kompleksnih struktura su-bitka. Druga naznaka je jezični karakter diskursa: analitičko-kritičko preslagivanje svakog pojma u egzistencijalno-analitičkom i fenomenološkom djelu, razotkrivanje, otkapanje povijesnih i tradicionalnih slojeva do izvornih, egzistencijalno razumljivih značenja nekog pojma, osvjetljavanje skrivenih aspekata te naravno kreativnost u tvorbi originalnih riječi i pojmova (Mit-dasein i sl.) ustupaju u političkim govorima mjesto objavama istina sastavljenim od neposrednih jednodimenzionalnih tvrdnji: 'narod ima dušu', njemački narod 'svoje najvlastitije', 'vlastitu volju' i sl. ${ }^{82}$ Nasuprot tomu, hermeneutičko-analitički su pojmovi bili dobiveni iz svakodnevnice i to u njenim modernim oblicima, a starogrčko kristaliziranje izvornog značenja kritikom povijesnih naslaga s jedne i otkrivanjem mogućeg značenja iz zamišljenog neposrednog iskustva ili imaginarnog doživljaja konkretnog svijeta $u$ antici s druge strane: pravo, istinito razumijevanje se u filozofiji dobiva metodom, a ona je put koji počinje onim što Heidegger zove "formalni oglas" (formale Anzeige). O tomu je Heidegger poučavao svoje studente. ${ }^{83}$

U gramatici nacističkog idioma riječi bez metodskog svjetla pak dovode smisao univerziteta u blisku vezu s narodom: smisao univerziteta izrasta iz naroda kao "naroda koji sebe zna" ${ }^{84}$ Oni egzistencijalistički pojmovi koje Heidegger povezuje s popularnim nacionalsocijalističkim vokabularom djeluju kao neke naljepnice

${ }^{80}$ http://www.spiegel.de/einestages/75-jahre-machtergreifung-a-948018.html. Za "listu Führera" glasalo je 92,2 procenta.

81 Vidi: Register.

82 GA 16, str. 192-193.

83 GA 29/30, str. 425.

84 "Volja za bit njemačkog univerziteta je volja za znanost kao volja za povijesni duhovni zadatak njemačkog naroda kao naroda koji sebe zna u svojoj državi”, RG, str. 6. 
unutar potpuno drugačijeg diskursa. Sve se mijenja, postaje jednostavno, izravno, neposredno kad se doda pridjev "völkisch", narodski. ${ }^{85}$ Od silnih kritičkih razračunavanja s modernom znanošću nema više ni traga, jer je sad po Heideggeru nastupilo vrijeme za "völkische Wissenschaft". Što je to i otkud to, ne objašnjava se. Ali se priroda (Natur) ne gleda više iz onog kritičkog ugla prema modernoj prirodnoj znanosti, kojoj se (natura) vehementno suprotstavljala grčka pv́бıৎ kao samo iz sebe izrastanje, nego: "priroda se očituje kao prostor naroda", ona se sad "oslobađa kao moć i zakon"; tu sad ta narodska antimoderna znanost pronalazi neke duboke procese koji zvuče kao eho popularnog biologizma čijim protivnikom se Heidegger uvijek predstavljao: spaja se "sakrivena predaja nasljeđivanja bitnih [prirođenih] svojstava i nagonskih usmjerenja prirode s ozbiljenjem narodne povijesti". U tomu se u pozitivnom smislu pojavljuje čak i tehnika koja je sad najedanput prava, istinska tehnika ("echte Technik"!) jer može svojom "oblikujućom moći” biti iskorištena. ${ }^{86}$

Taj neobjašnjeni, magični pojam naroda zajedno s drugim magičnim pojmom volje pruža tlo za utemeljenje novog univerziteta, mjesta znanja, odgoja i učenja, tako da se pitanje "udaljenosti znanosti od života" ${ }^{87}$ uopće neće postavljati. Heidegger voli još jednu magičnu sintagmu "Befehlskraft der neuen deutschen Wirklichkeit": snaga naredbe nove njemačke zbilje nastale nacionalsocijalističkom revolucijom tjera na odluku naroda koji zna svoj usud (Geschick) te ga izdržava, prihvaća.

Usprkos razlikama u tipovima diskursa ponešto može zazvučati kao eho iz prvotne faze. U njoj je taj diskurs bio još otvoren, kao ponuda za hrvanje o smislu bitka. Po mom sudu metafizička predodžba sudbine, neke imaginirane kobi je ono što zatvara koncept, koji je sâm kao propitivanje otvoren, i odvodi ga u slijepu ulicu ideja o veličini naroda, njegovoj duši i volji te nagađanja o nekom nalogu skrivenom u generacijama, mogućnostima iz naslijeđa. "Geschick", mitska i mitizirana predodžba kojoj nedostaje sve što odlikuje fenomenološko i hermeneutičko dolaženje do punog shvaćajućeg oblika nekog pojma, Heideggerova je originalna kreacija, ali se može vidjeti i kao naznaka spremnosti da se prihvati jedan isključivi svjetonazor u kojem su ekvivokacije tih njegovih pojmova (sudbina, volja, odlučnost, vođa) ključni kodovi.

Tako se i neka druga polazišta bez daljnjeg daju interpretirati kao nešto što se može izvući iz zapećka u nekom nepredvidivom političkom momentu. To je naravno moguće. Ali nije moguće da je netko tada (krajem dvadesetih) znao ili mogao

85 "Völkisch", pridjev jezički etabliran u nacionalsocijalizmu, i danas se upotrebljava u manjeviše pejorativnom značenju za (neo)nacističke, nedemokratske pozicije.

86 GA 16, str. 200-201.

87 Ibid., str. 306. 
znati da će nacionalsocijalisti i Hitler doći na vlast niti je itko mogao predvidjeti kakvu totalitarnu strahovladu će oni uspostaviti i osvajačku, uništavajuću politiku voditi. To već zbog toga što takvo što - kako se kaže - svijet još nije vidio.

Usprkos sličnostima, analogijama i ekvivokacijama ono što je zaista bitno je promjena Heideggerovog diskursa i semantike: naime ne radi se o tomu da su kao neke "teorijske" ideje primijenjene u sklop praktične politike, nego je taj diskurs Heideggerovih nacističkih govora i tekstova diskurs potpuno različitog karaktera. Dok je izoštravanje i preciziranje metode bilo srce fenomenologije i hermeneutike, u nacističkom diskursu se istine objavljuju, a na metodu se više ne obazire. Duh ta dva diskursa je ne samo različit - oni su uzajamno nespojivi.

\section{7. "Voljom" do novog univerziteta i odustajanje}

Upotreba termina iz fundamentalne ontologije je puko evociranje unutar jednog ideološkog konstrukta čija djelotvornost opet zavisi od zazvane volje. Mogućnost novog univerziteta Heidegger vidi u novoj njemačkoj zbilji u kojoj narod zna sebe, a studenti počinju svoj studij na temelju "svog narodskog znanja". ${ }^{88}$ Ta ideološka konstrukcija trebala je biti temelj novog univerziteta. Za njega je potreban i novi student. Volju novog studenta Heidegger je zamišljao kao otvorenost "državo-oblikujućim silama", "htjenje sljedbeništva" i "htjenje učenja"; ali on je u njemu htio vidjeti i radnika i prkosnog izazivača ("buržujskih") predavača i istraživača, koji agresivno kritički ispituje univerzitetsku elitu o smislu njihovog istraživanja i znanstvenih koncepata. ${ }^{89}$ "Novom studentu" je namijenjena funkcija pokretačke snage promjene. U njega on projicira buduću snagu koja će stvari postaviti na svoje mjesto, dakle prevladati okoštale strukture na fakultetima i vratiti se (tobože) iskonskom značenju znanja, učenja, životno relevantnom. To Heidegger emfatično formulira i u samom govoru: "Iz riješenosti njemačkih studenata da izdrže njemačku sudbinu u krajnjoj nuždi nastaje volja za bit univerziteta". ${ }^{90}$ Naravno, to pretpostavlja volju, zapravo Heidegger mora zamišljati da ona postoji, jer on nije vođa neke brojne grupe vidljivo nadahnute voljom za tom promjenom.

On je iz elemenata svoje filozofije razvio koncept nacionalsocijalističkog preoblikovanja univerziteta, ali to je bio njegov koncept odnosno njegov privatni nacionalsocijalizam; ${ }^{91}$ ipak bitno je da su koncepti za koje se zalagao kao nacistički rektor počivali na izvorno fenomenološkim kategorijama i hermeneutičkim deskripcijama iz Bitka $i$ vremena, a on ih je smatrao kompatibilnim s nacističkim

\footnotetext{
88 Ibid., str. 207.

89 “Njemački student kao radnik", ibid., str. 203 i d.

90 RG, str. 10.

91 Tako ministar poslije govora: ibid., str. 26.
} 
programima i namjerama. Naciste, one "prave", nisu nimalo zanimale Heideggerove ideje o pretvorbi univerziteta i kako se režim konsolidirao tako je to postajalo sve jasnije; i njemu samom je to ubrzo postalo jasno, iako vjerojatno nikad u istinskom smislu. Za naciste je reorganiziranje univerzitetskih sustava bilo usmjereno na zadobivanje instrumenata vlasti i njeno totaliziranje. Na raznim službenim sastancima, rektorskim konferencijama, gremijima novoosnovanih akademskih organizacija, raznim novim komisijama Heideggeru nije uspijevalo zadobiti podršku; iz pisama prijateljima, kolegama i supruzi te iz brojnih pritužbi i kritika na račun svojih konkurenata da se zaključiti da je on sa svojom koncepcijom bio potpuno usamljen odnosno nije zadobio podršku ni nacističkih prevratnika ni onih dijelova univerziteta koji su u pogubnim uvjetima pokušavali sačuvati ostatke tradicionalnog univerziteta, i da je toga bio djelomično svjestan. Heidegger i u svom osvrtu na rektorat navodi ta dva faktora kao objašnjenje, ${ }^{92}$ ali on nije svjestan činjenice, ili se nije želio suočiti s njom, da naime njegove projekcije preobrazbe univerziteta uopće, neovisno o tomu, nisu imale nikakvu podršku ni poklonike. Pri tomu je on zapravo računao s tom "voljom" u "pokretu" o kojoj je cijeli njegov projekt ovisio. Budući da se volja ne može 'posuditi' u vlastite svrhe, ostao je to usamljeni pokušaj bez neke povijesne pozadine, prethodnice ili društveno-znanstvene okoline. Povremena pretresanja tematike nužne reforme univerziteta s Jaspersom nakon njihovog legendarnog prvog susreta u proljeće 1920. stvarno ne mogu važiti kao ozbiljna inicijativa, iako su oni to druženje prozvali "borbenom zajednicom". Upućivanjem na to davno privatno razglabanje dvojice tada već redovnih profesora o nužnosti potpunog prevrata institucije kojoj su pripadali Heidegger je htio opravdati motive svog angažmana; taj davni susret je i za Karla Jaspersa vrijedan spomena u memoarima. ${ }^{93}$ Heidegger se poziva i na to kako su njegova kritika i njegovo raspredanje o potrebi fundamentalnih promjena na univerzitetu bili opće poznati. To se ipak sve nalazilo u sferi privatne razmjene mišljenja, a ona "borbena zajednica" se ne može čak nazvati ni nekom zavjereničkom grupom. I po tomu se vidi da Heidegger svoju grešku ne uviđa, u svakom slučaju ne želi vidjeti da su privatni razgovori jedno, a političko angažiranje nešto sasvim drugo. To je karakteristično za sve njegove osvrte po istoj shemi: "ja sam htio...", "meni je lebdjelo pred očima..." Time on ostavlja netaknutim te ideje i zanemaruje svoju osnovnu grešku koja se sastojala u tom po sebi iluzornom i zapravo apsurdnom konceptu odnosno njegovim pretpostavkama: volja, narod, sudbina. Iskreno kritičko propitivanje samog tog koncepta je prvi korak, a namjesto toga Heidegger misli da je s njim "preuranio", kao da bi za njegov

92 Ibid., str. 18.

${ }^{93}$ Karl Jaspers, Philosophische Autobiographie, München 1984; usp.: https://de.wikipedia. org/wiki/Martin_Heidegger_und_der_Nationalsozialismus i Reinhard Mehring, "Heidegger und Karl Jaspers Zerfall einer 'Kampfgemeinschaft'”, Heidegger-Handbuch, str. 337-342. 
prevrat univerziteta $i k a d$ moglo biti pravog trenutka, odnosno da nije imao potrebnu podršku - ali od koga je ona mogla doći? Na najbitnije, svoj jezik i njegove razlike nije obratio pažnju, konkretno na to kako su te njegove predodžbe, ideje, vizije, ono "što mu je lebdjelo pred očima" bile formulirane i kako je njegova semantika mogla doći u takvu blizinu krvoločne nacističke propagande. To bi bilo pravo polazište. Hipotetski: jer tako nešto bi bilo potpuno izvan Heideggerovih mogućnosti, čemu je sasvim konkretan razlog što je to uvelike i semantika u njegovim intimnim zapisima, vidljiva primjerice u sljedećem opisu "ciljeva":

Istinski ali najudaljeniji cilj: povijesna veličina naroda u ishođenju i oblikovanju moći bitka.

Bliži cilj: dolaženje sebi samom naroda iz njegove ukorijenjenosti i preuzimanje njegovog naloga kroz državu.

Sljedeći cilj: privremeno stvaranje narodne zajednice - kao vlastitosti (das Selbst) naroda.

I ta utopijska maštanja Heidegger povezuje s projekcijom "prekretničke volje kod mladeži” u kojoj vidi i mogućnost da se otkloni "opasnost od ponovnog srozavanja univerziteta u dosadašnji građanski način funkcioniranja". ${ }^{94}$

Smisao zamišljenog univerziteta - može se sumirajući reći - jest u smještanju znanja u središte narodne zajednice, ali jedne nove zajednice koja je nastala odnosno tek treba nastati kroz revoluciju. Dakle te zajednice još nema, nema ni tog univerziteta, kao što nema ničeg s čim Heidegger u svom konceptu računa. Svi elementi njegovog koncepta su hipotetične veličine: i narodska volja i prekretnička mladež i preuzimanje njemačke sudbine. Heidegger je stoga uvidio da ne može uspjeti u svojim namjerama i projektima te je dao ostavku na položaj rektora. ${ }^{95}$ Davši ostavku, Heidegger se nije sasvim povukao iz aktivnosti oko nacističke akademske politike, ali se može primijetiti postepeno i tiho odustajanje od volje kao vlastite kategorije. Sličan tretman dobiva i pojam "naroda" koji Heidegger - kao usput - podvrže primjerice 1936. kratkoj kritici konstatirajući kako "današnji svjetonazor" (tj. nacionalsocijalistička ideologija) negira kršćansku ideju transcendencije postavljajući narod (Volk) na to mjesto, tj. "kao cilj i svrhu sve povijesti". ${ }^{96} \mathrm{Na}$ osnovu tekstova je vidljivo da se on u tom - teško precizno odredivom - razdoblju okreće proble$m u$ volje odnosno Nietzscheu i njegovoj centralnoj kategoriji "volje za moć". Od 1936. do 1940. drži predavanja o Nietzscheovoj filozofiji i razračunavajući se s njegovim mišljenjem tj. "metafizikom" volje za moć kao essentiae zacrtava osnovne linije svog mišljenja kraja i prevladavanja metafizike. To je druga tema i zato samo

94 GA 94, str. 136 (iz 1933).

95 Za detalje o tomu vidi: RG, str. 4.

${ }^{96}$ GA 65, Beiträge zur Philosophie (Vom Ereignis), 1989, str. 24. 
ova primjedba na margini. Uostalom: univerzitet kao institucija se ovdje nigdje ne spominje. Ali u tekstovima iz tog perioda iskrsava novo shvaćanje volje: htjenje i predodžba. Čovjek - odnosno mi kao "htijući" - se u kritičkom tonu definira kao onaj koji se "hotimično probija u proizvodnju svijeta kao predmeta" ${ }^{97}$ Volja u tom shvaćanju postaje negativno htjenje iza pred-stavljanja svijeta kao pred-meta - i tako obvladavanja svijetom.

U jednoj bijesnoj napomeni zbog "zaborava bitka (des Seyns)" Heidegger upravo demonizira volju kao silu koja je "prestigla sva ljudska nedjela humanizma" s kojim je prije tristo godina nastupilo "doba svjetske noći". ${ }^{98}$

Opuštenije i staloženije proglašava Heidegger koju godinu kasnije: “... hoću ne-htijenje (Nicht-Wollen)... u smislu odbijanja volje". ${ }^{99}$

Nakon egzaltirano euforičnog zazivanja volje u svom nacionalsocijalističkom konceptu preobrata univerziteta Heidegger manje-više šutke gura cijeli koncept u pozadinu, a volja postaje potpuno negativna kategorija iza modernog svijeta znanosti, tehnike, proizvedenih stvari svake vrste, uništavanja prirode. U sveobuhvatnim kritičkim razračunavanjima sa svijetom u "zaboravu bitka" Heideggerov negativni stav prema univerzitetu se ne mijenja; dijagnoza stanja "univerziteta": "besmisao trijumfira". ${ }^{100} \mathrm{U}$ poslijeratnom periodu on je pun prezira prema faktičnom univerzitetu, naročito pokušajima razračunavanja s prošlošću i liberalizacije te uspostavljanja kritičke javnosti. ${ }^{101}$ Što ga ne sprečava da se osjeća povrijeđenim zbog otpuštanja s univerziteta $\mathrm{i}$ ogorčenim raznim postupcima nove uprave koje je smatrao nedostojnim.

\section{Stvarnost univerziteta i egzistirajući profesor Heidegger}

U Heideggerovim promišljanjima univerziteta ne nalazi mjesta nešto što mu je "najbliže i ponajčešće". To su njegov život i djelatnost na univerzitetu. Malo ironično bi se moglo reći kako - po njemu - tradicionalnoj metafizičkoj ontologiji ono samorazumljivo ne izaziva nikakvo propitivanje, pa je i Heideggeru njegova egzistencija

97 Holzwege (HW), "Wozu Dichter" (1936), Frankfurt a.M. 19725, str. 280. Heidegger u "Der Ursprung des Kunstwerkes" (1935) označava nasuprot tomu "htjenje" (das Wollen) "iz temeljnog iskustva Bitka i vremena" kao "znanje” i "ekstatično upuštanje egzistirajućeg čovjeka u nesakrivenost bitka", HW, str. 55.

98 GA 96 (1929-1941. g.), str. 189-190.

99 GA 77, str. 106.

100 GA 76, Leitgedanken zur Entstehung der Metaphysik, der neuzeitlichen Wissenschaft und der modernen Technik, prir. Claudius Strube, 2009, str. 85; radi se o rukopisima iz razdoblja od 1935. do 1955.

101 Suočavanje Nijemaca s nedjelima nacizma naziva on "bijednim puzanjem pod prismotrom planetarnog terora svjetske javnosti”, GA 87, str. 87, a ono je tada jedva počelo. 
kao profesora i nastavnika bezupitno samorazumljiva. Njegovo djelovanje i ponašanje bilo je potpuno usklađeno s običajima, etiketom, zahtjevima i očekivanjima akademske zajednice. Ono je to bilo i prije kada je kao gimnazijalac morao udovoljavati visokim zahtjevima i kriterijima te premošćivati izazove koje je postavljao strogi katolički profil škola u kojima je bio učenik. Za jedno odvažno i kreativno stvorenje to je donosilo teška poniženja koja je trebalo progutati na putu akademske uspješnosti. Heidegger je mislio da je ranije zaslužio mjesto redovnog profesora, ali to nije ništa neuobičajeno i ne dovodi u pitanje činjenicu da je on sukladno svim akademskim uzusima bio član univerziteta koje ima svoje predviđene postupke i hijerarhije. Na tom putu su neprijatelji isto tako normalna pojava kao i podržavatelji, s tim da su posljednji generalno rjeđi.

Ukratko, Heidegger nije nikad bio neki pobunjenik, neki outsider. Točno je znao što se treba raditi da bi se penjalo po ljestvici akademske karijere. Dapače, iz prepiski s kolegama - naročito s Jaspersom i Bultmannom - znamo da je i sam učestvovao u notornim zakulisnim igrama i intrigama oko popunjavanja katedri na raznim fakultetima i traženja raznih nasljednika za visoke položaje odnosno rošadama koje uz to idu. I privatna kritiziranja univerziteta su redovna pojava u komunikaciji između kolega. Među državno plaćenim činovnicima, pa tako i nastavnicima, salonski revolucionari isto tako nisu rijetka pojava, ali oni se naravno nikad ne upuštaju $u$ avanture $u$ realnosti koje bi mogle ugroziti njihov položaj. Heidegger je tu samo donekle iznimka: on se upustio u svoju rektorsku avanturu u momentu kada je mislio da su njegove ideje kompatibilne s nacionalsocijalističkim pokretom i novom državom. Dakle tu nije bilo revolucionarnog rizika, nego, dapače, otvarala se mogućnost napredovanja.

Ali on je svojom izuzetnošću ogromna iznimka u svakom pogledu. Svojim bogatim talentima, kreativnošću i originalnošću on je pravi događaj u freiburškim i marburškim predavaonicama: egzegezom fenomenoloških istraživanja, njihovim produbljivanjima, širenjem hermeneutičke metode i otvaranjem novih filozofskih horizonata kroz koncentraciju na fundamentalnu ontologiju i pitanje o bitku. Malo egzaltirano moglo bi se reći: on je revolucija univerziteta - u svom filozofskom dijelu. To sve ipak ne bi bilo moguće da se on na univerzitetu osjećao strano i nelagodno; ne, to je njegov biotop. On tu živi, oživi u svojim predavanjima i seminarima, u radu sa studentima i brizi za njih.

Ako igdje ima uhvatljivog smisla univerziteta odnosno filozofskog studija, onda je to u trenucima u kojima se nešto slično dešava: jedan nadahnuti profesor (ili profesorica) u usponu svoje kreativnosti i predavačko-pedagoške sposobnosti u intelektualnoj zajednici s pažljivim i talentiranim studentima. Heidegger je tu svoju intelektualno-egzistencijalnu realnost preskočio tražeći smisao univerziteta tamo gdje ga nikad nije bilo niti ga može biti. 
Slično se može primijetiti i u Heideggerovoj kritici liberalizma, naročito liberalnog ustroja univerziteta kako ga je osnovao Humboldt. To je predmet njegova prezira; naročito u svojim govorima - rektorskom i drugima - on se obrušava na "akademsku slobodu"102 u ime neke hipotetske i teško zamislive slobode kao "vezanosti”. Više od averzije se tu ne da naslutiti. Liberalnost, koliko god još kržljava, bila je nešto čemu je i Heidegger zapravo trebao biti zahvalan jer je obilježavala jedan dio realnosti u kojoj je on živio - kako na fakultetu tako i u slobodno vrijeme. Liberalni duh se početkom stoljeća taman toliko uspio probiti na univerzitetima da su i žene smjele studirati. To Heideggeru naravno nije izmaklo. Uostalom, njegove brojne seksualne afere blisko su povezane s time što je liberalno ustrojstvo univerziteta to omogućilo. Ta i svoju ženu Heidegger je upoznao kao studenticu ekonomije - ne samo svoju najpoznatiju ljubavnicu Hannah Arendt.

Njegove ljubavne afere su tipične za liberalni akademski milje, tj. njegov muški nastavnički kadar i nisu zamislive u onim idiličnim sredinama narodske egzistencije, među "usamljenim seoskim dobrima" između bregova i dolina Schwarzwalda, "zavičajnih brda", koje Heidegger preporuča studentima kao doživljaj kod planiranog logorovanja u ljetnom raspustu 1933. ${ }^{103}$

Kad ponosno opisuje svojoj supruzi Elfridi kako zbrinjava trogodišnjeg sina, Jörga, na putu vlakom svojim roditeljima u Meßkirchu dok ona u klinici očekuje bebu koju je zanijela u vanbračnoj vezi i kad se zna da će Heidegger upravo tom posinku povjeriti brigu oko svoje ostavine i izdavanja njegovih manuskripata, ${ }^{104}$ onda se tu očituje jedan vrijednosni sustav koji bi ipak prije pripadao liberalno urbanom nego konzervativno ruralnom stilu života, čije vrijednosti je Heidegger manifestno zastupao.

\section{Zaključak}

Rezimirajući, može se iz u ovom članku predstavljenoga zaključiti da je Heideggerov nacrt smisla univerziteta bio opterećen nizom pretpostavki koje su ostale nepropitane. Cilj u kojem bi se zacrtani smisao univerziteta trebao ozbiljiti je povratak početku znanosti u starogrčkoj filozofiji. Najmanji uvjet za to bi bila pretpostavka da postoji široka želja unutar raznih fakulteta da se znanosti utemelje u izvornom filozofskom propitivanju biti znanosti, iz pitanja o bitku u starogrčkom maniru. Takvo što Heidegger nije mogao pretpostaviti. Druga pretpostavka je da je nacio-

102 RG, str. 11.

103 GA 16, str. 97.

104 “Mein liebes Seelchen!” Briefe Martin Heideggers an seine Frau Elfride, 1915-1970, prir. Gertrud Heidegger, DVA, München 2005, str. 106, pisma od 28. jula, 6. augusta i 23. augusta 1920. 
nalsocijalistički pokret nošen voljom za radikalnom promjenom koja uključuje i volju za preobrazbom univerziteta $u$ Heideggerovom smislu. $U$ to je Heidegger htio vjerovati.

Treća pretpostavka je da se revolucija dogodila i da to preokreće cijeli narodski tu-bitak i na taj način sama nova zbiljnost tjera na preoblikovanje u svim sferama zajedničkog života pa tako i u znanostima, tj. na univerzitetu. To čudo se desilo nije.

Heidegger je 1933. navršio četrdesetu godinu života i stoga nije bespredmetno pitanje: kako netko u zrelim godinama i u naponu svoje stvaralačke snage dolazi u situaciju da vjeruje u takva čuda? Odgovor na to pitanje se gubi u nekim još neotkrivenim tajnama. Moja preliminarna teza je da je Heidegger krajem dvadesetih godina prošlog stoljeća zapao u puno dublju filozofsku krizu nego što sva naklapanja o poznatom okretu, obratu - "Kehre" - daju naslutiti. Ono što se pak pokazalo su Heideggerova prikrivanja i zamagljivanja. To bi podržalo nabačenu tezu. Dvostrukosti, koje su se pokazale, također. Trebalo bi dakle još dublje kopati da se možda odgrne tajna.

Heideggerova ambivalentnost prema univerzitetu je istog kova kao ambivalentnosti općenito: ona je rascjep između ljubavi i mržnje. Za njega je univerzitet bio sve. Ali Heidegger je htio da univerzitet bude nešto sasvim drugo. Samo: više od onog što je Heidegger filozofirajući na univerzitetu bio i živio ne postoji. Baš to je on preskočio, ignorirao. Tako dvostrukost njegove osobe odgovara njegovu ambivalentnom odnosu prema univerzitetu.

\author{
Dunja Melčić
}

HEIDEGGER'S EQUIVOCAL ATTITUDE TO UNIVERSITY

\title{
Summary
}

It is fair to say that university as idea was Heidegger's lifelong obsession. Young Heidegger believed that the power of education would become a generator of change. At the beginning this still was thought in the realm of Christianity and orthodox Catholicism of his heritage. It meant modern scientific scrutiny in the search for truth that was supposed to be real Christian truth. The most modern method of philosophy at the time was (Husserl's) phenomenology, which Heidegger was using for critical examination of the tradition in European philosophical, metaphysical thought. After the catastrophe of the Great War Heidegger, who was already teaching at the university, saw an urgent necessity of a radical turn from the traditional university to a completely new beginning starting with reflection on the first awakening of the quest about the being as such in ancient Greece. While this is no more than fantastic 
fancy, the true change and potentially new beginning was what he was doing at the university: his formidable lecturing and teaching, his profound and nevertheless down-to-earth thinking, his prolific pragmatic philosophy, its modern approaches and horizons-opening methods. In his striving for complete change of university Heidegger was taking his concrete existence and doings for granted. He did not give them a thought, instead he started to believe that nationalistic and antisemitic demolishing of the 'old world order' and fossilized institutions should just be the proper moment for the revolution of university and academic education to start. Until Heidegger had taken his rectoral post at the University of Freiburg (1933) and delivered his famous inaugural speech, nobody knew about his concept of 'completely new university', but he nevertheless believed that it should fit to the party schemes of 'national-socialist university'. The fundamental notion in this concept of university revolution is the "Will" ( der Wille), though assumed will. After the debacle of this shameful episode Heidegger still kept fantasizing about the other university, though skipping silently the 'category' of will; at the same time he was castigating himself for that political engagement - as is now known from the notorious "black notice-book" (2015). But no sincere analysis of the matter can be found in these private notices, rather all of these self-reflections end up in self-pitying à la: not that his concept was wrong, but the time was not right. Being a part of the criminal, murderous regime did not even emerge to his mind as a problem. That's the true reason for the notorious silence in the public about his guilt or at least responsibility during the Nazi regime. In the focus of this article is also Heidegger's twofold nature, not to say duplicity, which it sometimes was, too. This has many facets, but just comparing the language in texts of his Nazi-speeches and private notes on the one hand and his philosophical lectures and writings on the other, it becomes obvious that the two sides of Heidegger are deeply and totally irreconcilable. On their own they would be utter opposites; being parts of one person they constitute a paradox called Martin Heidegger. After he was sanctioned with deprivation of the licence to teach, Heidegger suffered a real trauma; what he was so bitterly missing was his active life, teaching and lecturing at the real existing university, not the imagined one he kept yearning for. Such too is the chasm that can be observed between Heidegger's critique of university's liberal spirit on one hand and the essential gains he had in his life exactly from this liberal new age spirit and the university as the modern institution and the only (precarious) possibility of free thinking since the time of early Greek thinkers on the other.

Keywords: Heidegger, University, "New Beginning”, Nazism, Will

Dunja Melčić doktorirala je filozofiju na Univerzitetu Johann W. Goethe u Frankfurtu. Bila je znanstvena suradnica na Max-Planck Institut für europäische Rechtsgeschichte.

Kontakt: Dunja Melčić. E-mail: dunja@melcic-mikulic.de 